THE PLACE FOR IMMIGRANTS IN TORONTO'S TRANSIT AND TRANSPORTATION CITY

\author{
by \\ Amardeep Kaur \\ B.A. in Politics, Trent University, 2008 \\ A Major Research Paper \\ presented to Ryerson University \\ in partial fulfillment of the \\ requirements for the degree of \\ Master of Planning \\ in \\ Urban Development
}

Toronto, Ontario, Canada, 2013

(C) Amardeep Kaur 2013 


\section{AUTHOR'S DECLARATION}

\section{AUTHOR'S DECLARATION FOR ELECTRONIC SUBMISSION OF A MRP}

I hereby declare that I am the sole author of this MRP. This is a true copy of the MRP, including any required final revisions.

I authorize Ryerson University to lend this MRP to other institutions or individuals for the purpose of scholarly research.

I further authorize Ryerson University to reproduce this MRP by photocopying or by other means, in total or in part, at the request of other institutions or individuals for the purpose of scholarly research.

I understand that my MRP may be made electronically available to the public. 


\title{
THE PLACE FOR IMMIGRANTS IN TORONTO’S TRANSIT AND TRANSPORTATION CITY
}

(C) Amardeep Kaur, 2013

\author{
Master of Planning \\ in \\ Urban Development \\ Ryerson University
}

\begin{abstract}
This study conducted qualitative interviews with nine immigrants on their experiences of public transit in Toronto. It synthesizes and builds on existing data that indicate that immigrants, especially women, highly depend on public transit despite settling in the peripheries of Toronto, away from subway lines and close to major highways. I identify gaps in existing academic and policy debates on transportation planning in Toronto and propose an environmental justice framework that is grounded in immigrants' experiences of navigating public transit and their spatial locations. The research findings highlight the limited affordability of public transit, the poor servicing and connectivity of bus networks, and the resulting barriers to accessing work opportunities across the region. I further analyze the role of the built environment in limiting or facilitating access for gendered activities such as grocery shopping and traveling with children. The paper concludes by highlighting the need for new directions in transit policy and planning that can better address the changing demographics and social and spatial divisions in the city.
\end{abstract}

Keywords: immigrants, transportation, environmental justice, public transit, gender, Toronto 


\section{ACKNOWLEDGEMENTS}

This graduate research was made possible through the support of a Social Sciences and Humanities Research Council (SSHRC) Grant and an Ontario Graduate Scholarship, These provided the financial resources throughout the Master's program and allowed me to embark on this academic and urban planning inquiry. I wish to thank professors Derek Hall, Nadine Changfoot and Haroon Akram-Lodhi, who encouraged me to go to graduate school and provided references for my scholarly pursuits.

I am grateful to Cheryl Teelucksingh who supervised and guided me through this graduate study with valuable insights on the research matter and lent me her expertise in environmental justice. Joseph Springer provided important feedback to this project as a second reader and gave inspiration and support to me in his housing class. I also wish to thank the professors in the School of Urban and Regional Planning - Sandeep Kumar Agrawal, Raktim Mitra and Beth Milroy - who offered valuable learning opportunities in their classes and opened up the intellectual possibility of this research.

Many classmates and colleagues who also shared this journey of graduate work and urban planning provided key motivation and support, especially in the final months.

This project would not have been possible without the willingness and generosity of the many immigrant participants who volunteered their time for this research and shared their experiences of transit in the city. As well, I wish to thank my friends, and especially my loved ones, with whom I have had many deep conversations, and who offered ideas on recruitment and supported me in numerous ways throughout the journey. Finally, I am truly grateful to my dear family who has always supported me and my educational pursuits. 
I dedicate this paper to my mother 


\section{TABLE OF CONTENTS}

Author's Declaration $\quad$ ii

Abstract iii

Acknowledgements iv

Dedication $\quad$ v

Table of Contents vi

List of Tables and Maps viii

CHAPTER 1 - INTRODUCTION TO THE TRANSIT PROBLEM

Introduction: the Transit Problem 1

City of Toronto Context 2

Population growth and intensification $\quad \mathbf{3}$

Growth and immigrants $\quad 4$

Purpose of Study $\mathbf{5}$

Immigrants Settlement Patterns and Links to Transport Networks $\mathbf{6}$

Research questions $\quad \mathbf{1 0}$

CHAPTER 2 - TRANSPORTATION PLANNING IN TORONTO

From transportation supply to travel demand management $\quad \mathbf{1 2}$

$\begin{array}{ll}\text { In search of regional transportation governance } & \mathbf{1 4}\end{array}$

Current transportation plans and strategies $\quad \mathbf{1 5}$

The Official Plan $\quad 15$

Zoning By-Laws $\quad \mathbf{1 6}$

Transit City Light Rail Transit $\quad \mathbf{1 6}$

Transit City Bus Network $\quad \mathbf{1 8}$

MoveOntario $2020 \quad 19$

The Big Move 19

CHAPTER 3 - ENVIRONMENTAL JUSTICE FRAMEWORK AND

LITERATURE REVIEW

Social Exclusion in Transportation $\quad \mathbf{2 1}$

Environmental Justice $\quad \mathbf{2 2}$

Immigrants and Transportation $\quad \mathbf{2 5}$

$\begin{array}{ll}\text { Gender and Transportation } & \mathbf{2 7}\end{array}$ 
CHAPTER 4 - METHOD AND STUDY DESIGN

Methodology

Research Method

Participant Demographics

CHAPTER 5 INTERVIEW ANALYSIS

Themes 33

Public Transit Use and Dependence $\quad 33$

Housing and Transportation $\quad \mathbf{3 4}$

Transit and Work Opportunities $\quad 37$

Cars and Driving Licenses $\quad 38$

Costs $\quad 39$

Transit and Grocery Shopping $\quad 41$

Accessibility and Built Environment $\quad \mathbf{4 2}$

Transit Service Problems $\quad \mathbf{4 4}$

Other Issues: Discrimination, Isolation and Environmental Problems $\quad \mathbf{4 6}$

Improvements $\quad \mathbf{4 7}$

Key Lessons from the Interviews 49

CHAPTER 6 MOVING FORWARD: IMMIGRANTS AND

TRANSPORTATION POLICY

Gaps and Challenges in Transit Strategies $\quad \mathbf{5 3}$

'Choice Riders' and Transit-Dependent Riders

Climate Change, Global Cities and Environmental Justice $\quad 55$

Smart Growth but where?

Policy Recommendations $\quad \mathbf{5 6}$

Outlook $\quad \mathbf{5 7}$

Appendix A - Interview Guide $\quad \mathbf{5 9}$

References $\quad 61$ 


\section{LIST OF TABLES AND MAPS}

Tables:

Table 1.1 Immigrant Populations in Toronto

p.4

Table 4.1 Participant Demographic Characteristics

p.32

Maps:

Map 1.1 City of Toronto Key Map p.2

Map 1.2 Average Income Changes Across Toronto, 1970-2005 p.6

Map 1.3 Immigrant Settlement in Toronto, $1961 \quad$ p.8

Map 1.4 Immigrant Settlement in Toronto, 2001 p.8

Map 1.5 Low-Income, Poor Walkability and Post-war high rise apartments p.9

Map 2.1 Population growth along highway and rail lines in GTA p.12

Map 2.2 TTC subway stations with low to medium population densities within p.13 a 500 metre radius

Map 2.3 Original Transit City LRT Plan approved in 2007 by the TTC p.17

Map 2.4 Plan for Bus Rapid Transit in Toronto p.18

Map 2.5 Approved Phase 1 of LRT lines under Metrolinx's 5 in 10 Plan p.20 


\section{CHAPTER 1 - INTRODUCTION TO THE TRANSIT PROBLEM}

\section{Introduction: the Transit Problem}

In recent years, there have been many debates in transportation planning and transit policy in Toronto amongst decision-making stakeholders. These debates have tended to focus on the personal preferences of politicians, technology, financing and

commuter traffic. Amongst the issues debated are what kind of railway systems - subway or light rail (LRT) - should be implemented, what priority should be given to a downtown relief line and what is the potential for public-private partnership. Limited, if any, stakeholder discussion and research have taken place on the spatial distribution of public transit, structural issues in transportation planning affecting social-economic disparities and the social dimensions of transportation in Toronto.

Yet, Toronto's inner city, along the Bloor and Yonge subway lines, is increasingly being fortified by white wealthy people (Hulchanski, 2010). Lower-income and immigrant communities are now located at the peripheries of Toronto in many of the high-rise apartment towers - built for an auto-centric urban environment along major highways (Hulchanski, 2010). The thin wall of middle-class population in Toronto is disappearing. Current changes to transportation in Toronto, with 2015 Pan Am Games around the corner, invite particular forms of investment and interest in rapid transit, Airport Express train and subway extension to York University. At the same time, service cuts to bus routes, as well as weekend and night hours have a bearing on transitdependent communities. Following the Ontario government's scaling back of promised capital funding for local LRT projects, as well as the political crises over Toronto's subway versus LRT contest, peripheral communities in North York and Scarborough will now have to wait until 2021 for better connectivity with the delayed Sheppard LRT.

Some emerging studies (Hulchanski, 2010; Hess and Farrow 2011; Toronto Public Health 2012; Levy 2013) are specifically calling for improvements to public transit in Toronto's priority neighbourhoods, apartment high-rises and inner suburbs 
where many immigrants are increasingly located. These studies note the higher usage of public transit amongst the immigrant groups and yet the lack of transit accessibility and walkability in neighbourhoods. There is a need for a comprehensive understanding of the travel behaviour and patterns of immigrants - particularly recent immigrants in Toronto. More specifically, it is important to analyze immigrants' settlement locations, transportation choices, and how transit experiences are gendered, in order to better inform the upcoming rapid transit development and expansion debate in the city.

\section{City of Toronto Context}

The City of Toronto, situated in Southern Ontario, is the largest municipality in Canada in terms of population, at 2.4 million people (Statistics Canada, 2012a). As part of the Greater Toronto and Hamilton Area (GTHA) and Greater Golden Horseshoe subregion, it is also the largest urban region in Canada and serves as a financial and commercial hub at its downtown district.

\section{Map 1.1 City of Toronto Key Map}

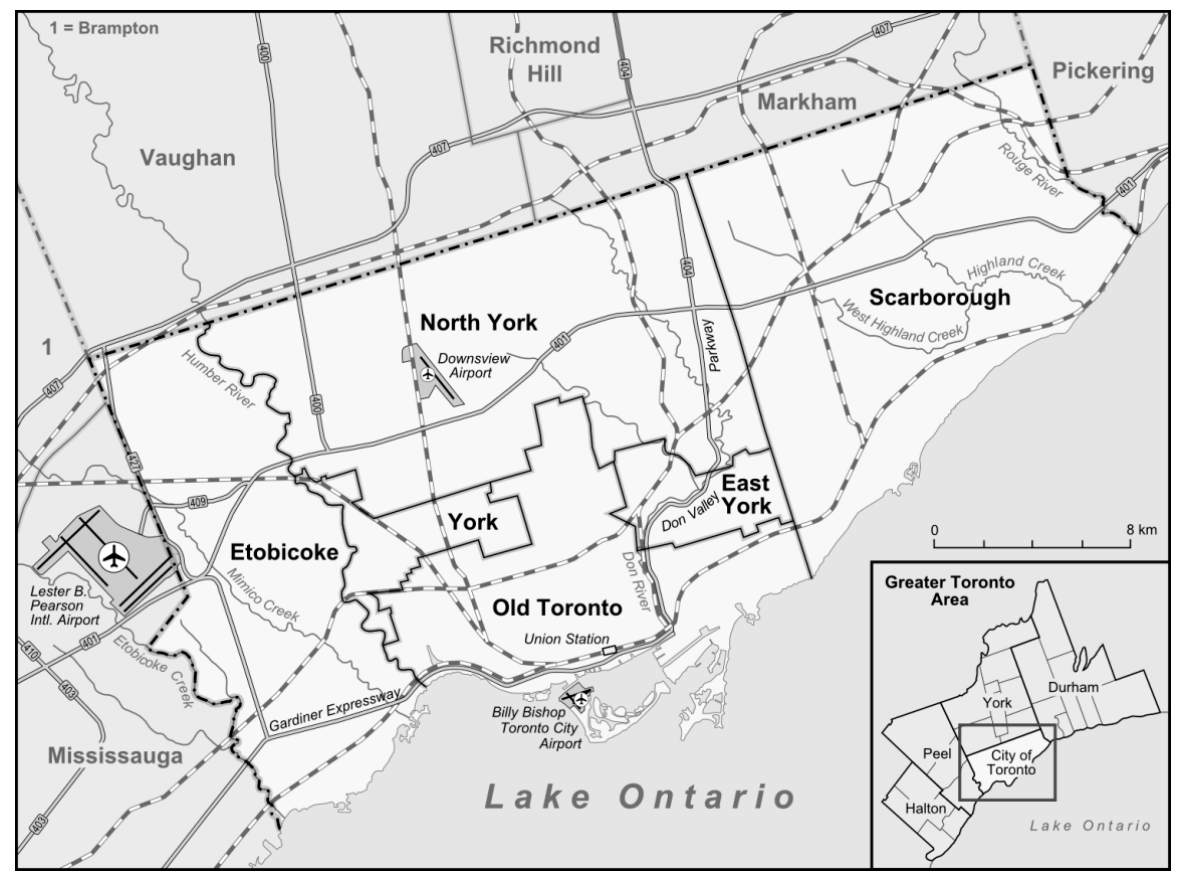

The city's geographical boundaries consist of large transportation corridors and natural water bodies. As seen in Map 1.1, it is bounded by Lake Ontario to the south, 
Steeles Avenue to the north, Etobicoke Creek and Highway 427 to the west, and Rouge River to the east. The Gardiner Expressway and Don Valley Parkway are municipal expressways that connect to Highway 401 - a provincial highway that runs through the northern portion of Toronto. Rapid transit within Toronto is provided by Toronto Transit Commission (TTC) subway lines with an orientation and emphasis to serving Toronto's downtown core. The inner rapid transit is connected with commuter rapid transit - GO Transit - primarily at Union Station.

Toronto's subway lines run through the centre of the city. The Yonge-Spadina Ushaped line runs north and south and first opened in 1954 (TTC, n.d.). The BloorDanforth line runs west to east and opened in 1963. Scarborough Rapid Transit - a medium-capacity rail transit - opened in 1985 . The recently built inner suburban Sheppard line, consisting of four stations, opened in 2002. As such, much of the inner suburb region depends on buses for public transit. GO Transit - a regional commuter rail service first started in 1967 - has grown to a seven-line commuter rail network that brings exurban residents into Union Station, the downtown business hub of Toronto (GO Transit, 2008: 6-7). It is operated by Metrolinx - previously the Greater Toronto Transportation Authority, which was established in 2006 by the Government of Ontario. (Metrolinx, 2008).

\section{Population Growth and Intensification}

Between 2006-2011, Toronto experienced a growth rate of 4.5\% (City of Toronto, 2012). However, this is considerably less than the growth rate of rest of the GTHA at 12.5\%. By 2031, the population of Toronto is forecast to be 3 million (Ontario, 2006). Provincial plans for the subregion and for Toronto require particular attention to the future transit needs of the city. The Provincial Policy Statement calls for intensification and redevelopment of existing built-up areas and settlements (Ontario Ministry of Municipal Affairs and Housing, 2005). More importantly in 2005, a recent provincial act

- The Places to Grow Act - put in place a new legislative planning framework for growth management and economic opportunities in the province (Government of Ontario, 2005). Building on Places to Grow, the provincial growth plan for the Greater Golden 
Horseshoe (Ontario Ministry of Infrastructure, 2006) sets up a 25-year plan that aims to improve on economic opportunities in the subregion and manage population growth. A key tenet of the plan is smart growth, which promotes mixed-use and sustainable intensification and transit-oriented design. The plan puts in place strategies and policies to revitalize existing urban communities through broader transit options and curb sprawl through urban and infill intensification. This includes minimum targets of population growth in identified urban growth centres. Within Toronto, these designated growth areas consist of Downtown, Scarborough Centre, Etobicoke Centre, Yonge-Eglinton Centre and North York Centre. The Greenbelt area in the Greater Golden Horseshoe, established in 2005, also plays an important role in the future development of Toronto. As part of a strategy to curb urban sprawl and protect natural habit, the Greenbelt area will redirect development through housing intensification in Toronto as well as enable a shift from auto-centric transportation to rapid transit in order to accommodate intensification.

\section{Growth and Immigrants}

Immigrants are increasingly the source of population growth in large Canadian cities. Between 2006 and 2011, two-thirds of all growth in Canada was attributed to immigration (Statistics Canada, 2012b: 2). Of the 1.1 million new immigrants that landed in Canada between 2001 and 2006, a quarter settled in City of Toronto (2007). In Toronto, immigrants form over 50\% of the population (Statistics Canada, 2007). In 2006, half of the immigrant populations in Toronto had arrived only within the last 15 years, as seen in Table 1.1 below (Statistics Canada, 2007).

Table 1.1 Immigrant Populations in Toronto (Source: Statistics Canada, 2007)

\begin{tabular}{|l|r|l|l|}
\hline & \multicolumn{1}{|l|}{ Total } & $\begin{array}{l}\text { \% of total } \\
\text { population }\end{array}$ & $\begin{array}{l}\text { \% of total } \\
\text { immigrant population }\end{array}$ \\
\hline Total population & $2,476,565$ & & \\
\hline Non-Immigrants & $1,184,235$ & $48 \%$ & \\
\hline Immigrants & $1,237,720$ & $50 \%$ & $48 \%$ \\
\hline Before 1991 & 592,490 & $24 \%$ & $30 \%$ \\
\hline $\mathbf{1 9 9 1}$ to 2000 & 377,380 & $15 \%$ & $22 \%$ \\
\hline 2001 to 2006 & 267,855 & $11 \%$ & \\
\hline Non-Permanent Residents & 54,610 & $2 \%$ & \\
\hline
\end{tabular}


Of course, it is important to note that immigrant populations are heterogeneous in terms of their diasporic origin and display unique and differential settlement patterns particularly in their housing choice and location, as some studies have noted (Ghosh, 2007; Agrawal, 2008). As well, immigrant populations are diverse in terms of class, with some able to access more opportunities such as home ownership or progressive housing careers more so than others (Murdie, 2002). Many immigrants are racialized as they come from the Global South and thus have different economic opportunities from white immigrants and white Canadian-born populations. In 2006, the top five source countries for immigrants arriving in Toronto CMA were India, China, Pakistan, Philippines and Sri Lanka (Statistics Canada, 2008).

Statistics reveal that immigrants have a higher public transit usage than nonimmigrants in Canada. In Toronto Census Metropolitan Area (CMA), 36.3\% of immigrants use public transit to go to work while only $20.7 \%$ of Canadian-born people use public transit for work (Heisz \& Schellenberg, 2004: 172-73). A similar trend of greater public transit use amongst recent immigrants is also seen in Vancouver and Montreal CMAs. This highlights important travel patterns and behaviour amongst immigrant populations across large Canadian cities. While the province and the City of Toronto have shifted their focus from auto-centric development to more multi-modal transportation networks and supporting rapid transit (Metrolinx, 2008), there has been limited discussion on immigrants' transportation needs. In light of the changing demographic landscape, there is a need for a transportation strategy that is based on a deeper understanding of how immigrant groups and communities travel across the city. This should aim to develop and improve transit infrastructure with a view to better integrating recent immigrants' settlements and travel patterns.

\section{Purpose of Study}

The purpose of this research is to address the current shortcomings of transit decision-making by bringing to the fore questions of access, socio-economic disparities, and the spatial polarization of Toronto in terms of immigrant settlement patterns and travel experiences. I will build on existing research, which shows that immigrants and 
low-income groups are concentrated in the peripheries, away from the subway lines (Hulchanski, 2010). This picture of social division, as the trends presented next show, underlines the need for an in-depth qualitative study of immigrants' use of and experiences with transit and their corresponding housing and employment locations.

\section{Immigrant Settlement Patterns and Links to Transport Networks}

Central to this study about transportation is a spatial analysis of immigrant settlement and the socio-economic trends that accompany it. There is now a growing body of literature that has begun to map neighbourhood and regional poverty trends, and to contextualize these with social compositions and housing concentrations amongst immigrants and ethnocultural groups (United Way Toronto, 2011; Maaranen, 2006; Walks \& Bourne, 2006; Hulchanski, 2010).

Map 1.2 Average Income Changes Across Toronto, 1970-2005 (Source: Hulchanski, 2010)

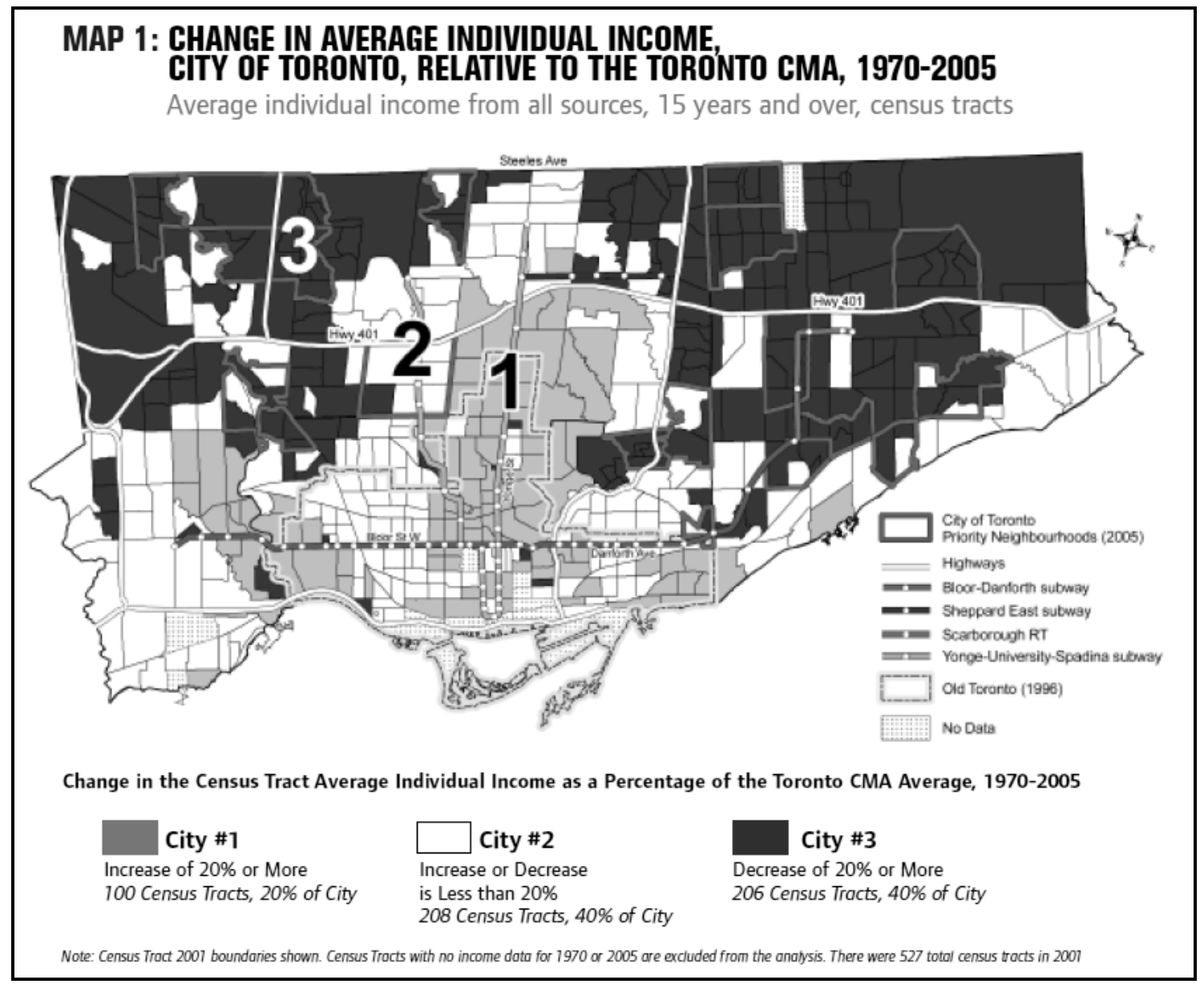


The Three Cities Within Toronto report maps socio-demographic patterns and trends across Toronto from the 1960s to the 2000s (Hulchanski, 2010). Through a visual exploration and Geographical Information Systems (GIS) mapping of Toronto's census tract data, the research examines socio-economic polarizations within Toronto and significant transitions in the spatial location of low-income people, immigrants and visible minorities. A key finding of the study highlights that the inner city (along the Bloor and Yonge subway lines) is increasingly being fortified by white wealthy people and that lower-income racialized communities are now located in the peripheries of Toronto, with a disappearing thin wall of middle-class populations in between (see Map 1.2 on previous page). In 2006 , the white population constituted $82 \%$ in City $\# 1$, i.e. the inner city (Hulchanski, 2010: 11). Furthermore, the proportion of immigrants within the inner city declined from $35 \%$ to $28 \%$ in the period of $1971-2006$. In contrast, in the peripheries, it rose from $31 \%$ to $61 \%$ (Hulchanski, 2010: 11).

City \#3 also encompasses all the thirteen "priority neighbourhoods" such as JaneFinch and Malvern that were identified in 2005 by United Way Toronto and City of Toronto as places that need investment in social services and programming (Hulchanski, 2010). These "priority neighbourhoods" have often been labeled as areas with high social problems, crime and poverty, and are associated with a high concentration of immigrants and racialized communities. 
Map 1.3 and Map 1.4 Immigrant Settlement in Toronto, 1961 and 2001 (Source: Maaranen, 2006)

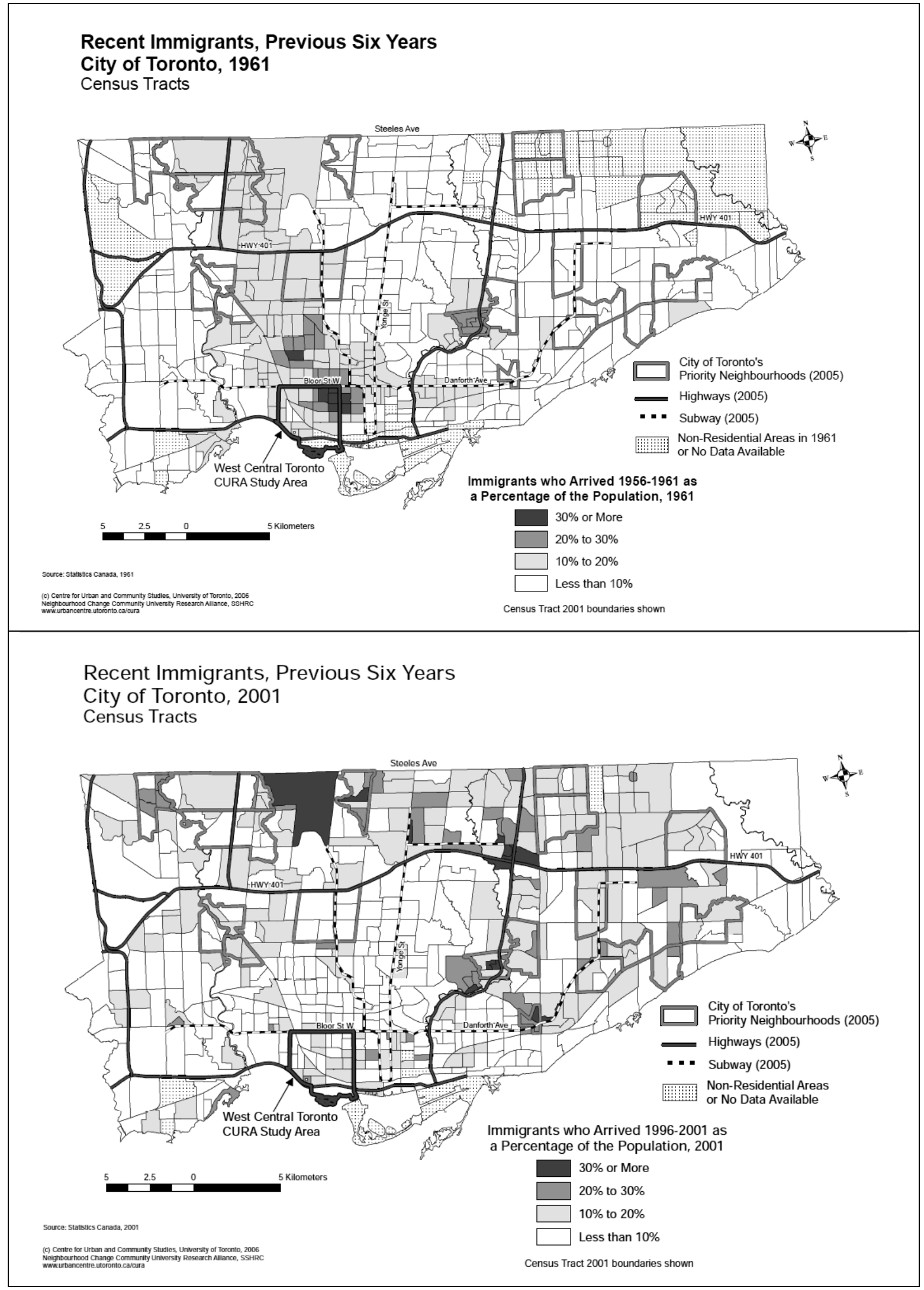


There have been stark changes in immigrants' settlement locations in Toronto. Map 1.2 and Map 1.3 in the previous page show immigrant settlements with patterns that strongly cohere with the three cities argument put forth by Hulchanski. In the 1960s, immigrants generally settled in the core of the city in Toronto. On the other hand, in 2001, immigrant settlements are predominately shown to be in the peripheries of Toronto. As such, between 1961-2001, there is a clear shift in where immigration reception is located in the City of Toronto, with census tracts in the former municipalities of Etobicoke and Scarborough becoming the key receivers of immigrants. These emerging areas of settlement are strongly marked by highway corridors and are also further away from the Yonge-Spadina and Bloor subway lines.

Map 1.5 Low-Income, Poor Walkability and Post-war high rise apartments (Source: Toronto Public Health, 2012)

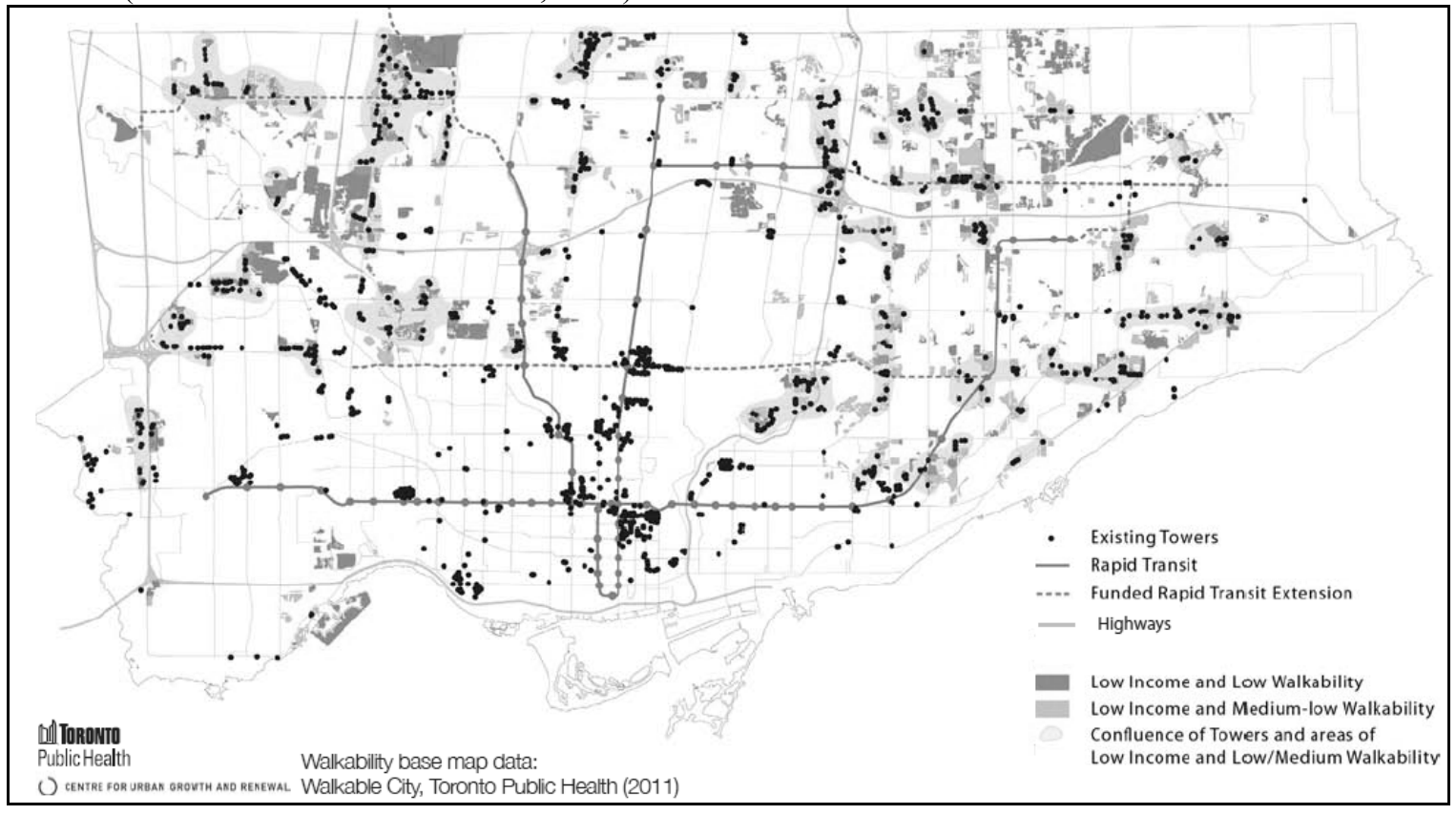

Moreover, Map 1.5 (above) highlights pockets of low-income groups and low walkability in Toronto's high-rise apartments in the peripheries of the city. The map indicates a concentration of existing towers along the highway 401 and away from the subway in the inner suburbs. Toward Healthier Apartment Neighbourhoods, a report from Toronto's Public Health, further notes that these areas have higher health and environmental risks (Public Health, 2012). The report notes higher rates of diabetes and poorer access to fresh food alongside low-income populations (Public Health, 2012). 
Considered together, the data presented on these maps suggest that immigrant and low-income communities are concentrated in segregated and isolated locations along the edges of the highway 401 and along poorly serviced public transit routes. There is, then, a need for transportation and land-use planning and policy to respond to these changing demographics and recent immigrant settlement patterns, as well as the uneven environmental risks they reflect.

Given that a study of immigrants' use of transit is complex, a multi-dimensional lens is needed that can look into spatial locations, gendered experiences, social inequities as well as procedural ones. On the one hand, immigrant communities - particularly women and children - may have limited choices in their mode of travel and need to rely on public transit. On the other hand, the poor servicing and lack of improvements of transit in the peripheries in Toronto may mean that lower-income communities are forced to rely on cars in order to get to work. In both cases, an environmental justice framework informs us how the experiences of spatial segregation and transportation barriers are racialized. Transportation planning, policy and ongoing decision-making can benefit from this multi-dimensional lens in addressing the complexity of socio-economic access concerns that are interconnected with transit, particularly for immigrants.

\section{Research Questions}

I will make use of an environmental justice framework that I unfold in my literature review in order to enhance comprehension of the transportation-related challenges facing Toronto's growing immigrant community. Through this lens, my research will address the following questions:

1. What is the impact of transportation planning decisions on spatialized social divisions in Toronto?

2. What are the barriers to accessing public transit that immigrants face?

3. What shifts in planning strategy and policy are needed for addressing the transit and social problems? 
This chapter has set the stage for the need for a focused study on immigrants and transportation in Toronto. I have used some existing Geographical Information Systems (GIS) data and maps such as those synthesized by Cities Centre at University of Toronto to lend perspective on spatial locations of transit lines and immigrant settlement patterns. In Chapter 2, I start with an overview of transportation policies and projects relevant to my topic and discuss existing transportation plans that will inform my analysis of transit strategies and their impact on immigrant communities. In particular, I trace the shift from autocentric transportation supply planning to multi-modal transportation demand management. I outline policies in Toronto's Official Plan, Zoning By-Laws and current rapid transit projects as they form an important component of my discussion. In Chapter 3, I lay the groundwork for a need of a multi-dimensional framework, centered on environmental justice principles, in order to tackle this complex planning topic. I will conduct an interdisciplinary analysis of the existing literature on immigrants' transportation choices and experiences and how barriers to transit and mobility are gendered. Chapter 4 introduces my research methodology. In order to address current methodological shortcomings in research on immigrant's travel experiences, I have conducted qualitative interviews with nine immigrants across Toronto to lend perspective on their travel behaviour, choices and needs. Subsequently, in Chapter 5, I analyze the findings from the interviews. These include themes such as participants' strong concern for the affordability of public transit, the poor servicing and connectivity of bus networks, and their resulting difficulty in accessing work opportunities across the region. Moreover, I analyze the role of the built environment and accessibility for gendered activities such as grocery shopping and travelling with children. My final chapter will discuss my analysis and findings as they relate to current transportation directions. I will identify gaps in existing transit strategies and provide policy recommendations that can better address the changing demographics and spatial patterns of the city. 


\section{CHAPTER 2 - TRANSPORTATION PLANNING IN TORONTO}

\section{From transportation supply to travel demand management}

As with most North American cities, transportation supply characterized Toronto's post-war era with an emphasis on supply planning, that is, building and providing roads, expressways and highways. Highway 401 is a provincial highway that runs from the southwest of Southern Ontario all the way to the border of Quebec through Toronto. The Gardiner Expressway and Don Valley Parkway form the major municipal expressways in Toronto and connect to Highway 401. Highway 407 is a toll road that runs just outside of the northern boundary of Toronto.

Map 2.1 Population growth along highway and rail lines in GTA (Mitra, 2007)

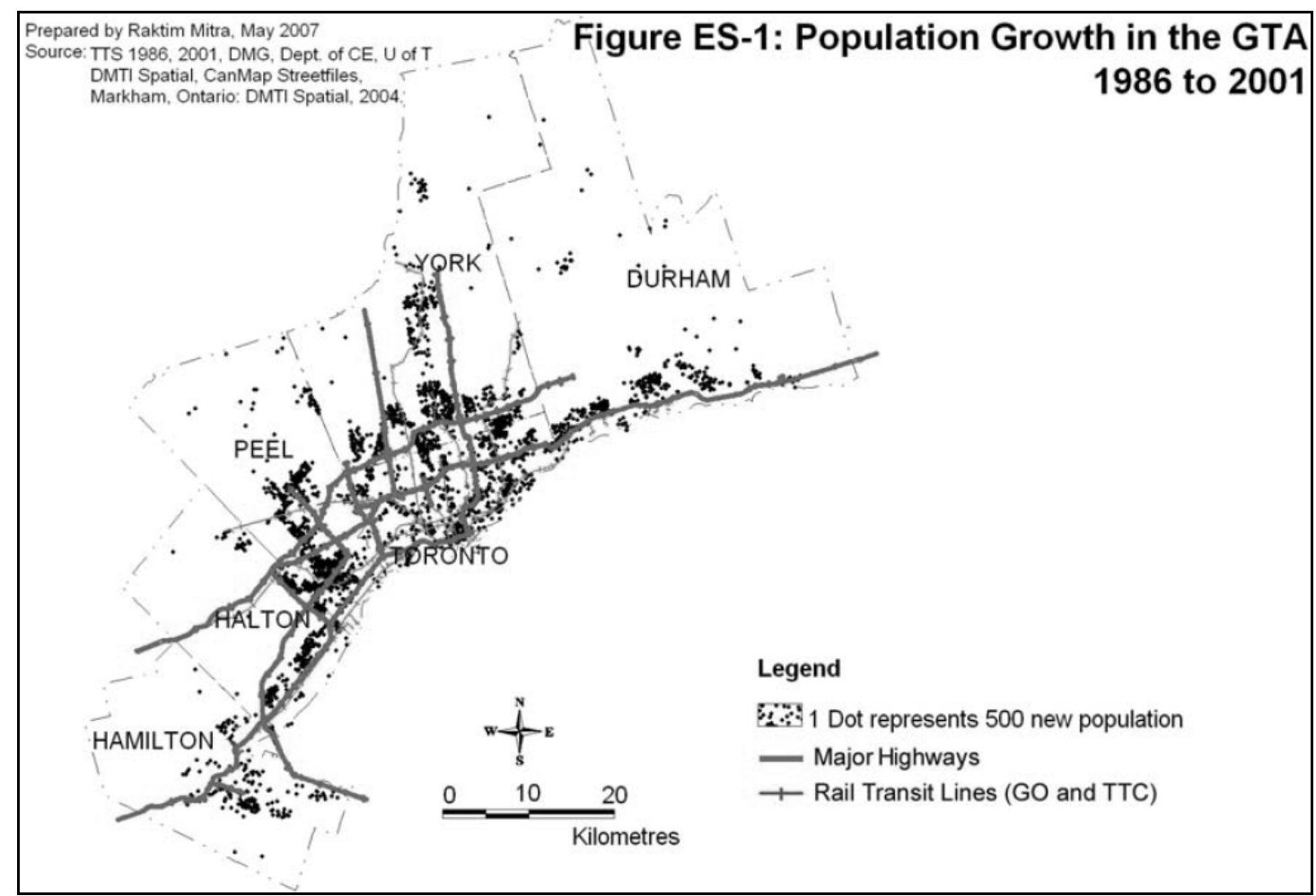

In addition to the development of highways in Toronto, there are two main subway lines. The Yonge-Spadina subway line opened in 1954 and the Bloor-Danforth line opened in 1963 (TTC, n.d.). In the 1970s, the emphasis shifted away from highdensity inner city transit to lower density commuter transit in the outer suburbs (Levy, 
2013). GO Transit formed the key mode of suburban commuter transit to and from Toronto's downtown. Growth followed the transportation corridors with high-rise apartment development on the edges of the highways. As a result, urban sprawl stretched outward along highways and GO Transit commuter rail lines leading to increased suburbanization in the Greater Toronto Area as seen in Map 2.1 on the previous page.

Map 2.2 TTC subway stations with low to medium population densities within a 500 metre radius (Source: own map)

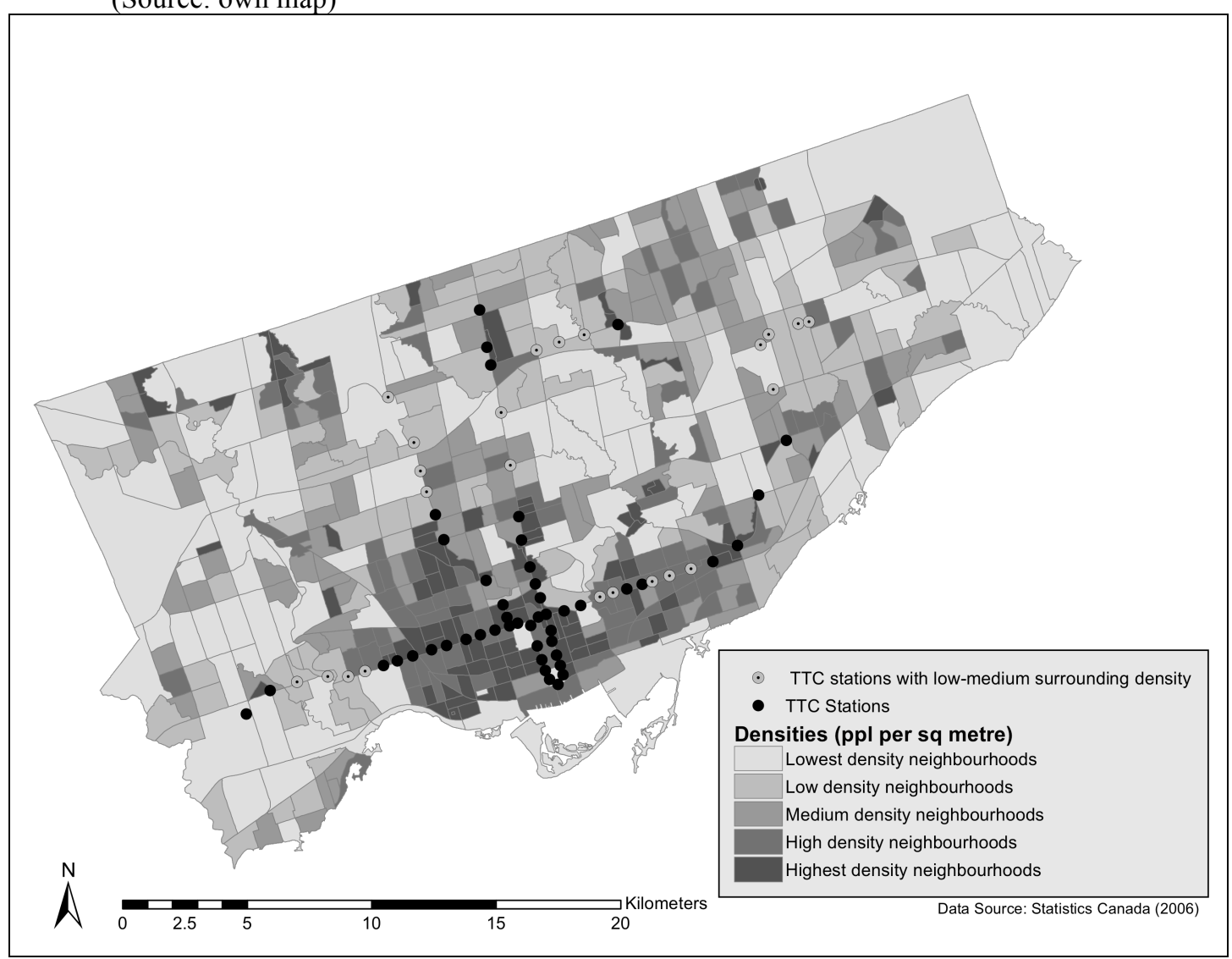

In other words, transportation supply planning combined with poor land-use integration created an urban sprawl problem. Edward Levy (2013), a transportation planner, notes that when the Bloor-Danforth subway was built and Yonge-Spadina extended, not all stations received the growth needed to maintain the subway network. As seen in Map 2.2 (above), several subway stations on the Yonge-Spadina line and Bloor line are surrounded by low or medium density neighbourhoods, even after decades of operation. NIMBYism (Not In My Backyard) and sometimes difficulty in assembling land parcels for high-rise or mixed-use development often prevented intensification and 
higher density along the subway lines (Levy, 2013). The result is that high-rise apartment developments were approved on greenfield land in the inner suburbs at the edges of highways and away from the high-order rapid transit corridors. The built environment and land-use catered to 'Tower in the Park' designs in neighbourhoods such as Rexdale and Thorncliffe Park. These autocentric developments provided residents with easy access to highways. Many of these towers and areas have been identified as having high levels of poverty (United Way Toronto, 2011). Levy notes that Toronto's failure to rezone the transit corridors to higher density may have led to and created many of Toronto's "priority neighbourhoods":

The most regrettable aspect of the failure to maintain the rapid transit/complementary rezoning link relates to Toronto's 'Priority Neighbourhoods.' Few are served by high-capacity (rail) transit. Unfortunately, given the 2012 controversy over transit at the municipal level, several 'Priority Neighbourhoods' will not benefit from such significantly improved public transit service for many years. (Levy, 2013; n.p.)

Since the 1980s and particularly in recent years, there has been a shift from transportation supply to travel demand management (TDM). This shift comes in the face of climate change, environmental pollution and recognition of the limitations of fossil fuels. A TDM approach and planning primarily concerns itself with altering demand and reducing pressure through programs such as carpooling and high-occupancy vehicle (HOV) lanes. In policy terms, this kind of mobility management tries to moderate the way people travel rather than building an endless supply of roads and highways.

\section{In search of regional transportation governance}

Between 1954 and 1998, Metropolitan Toronto consisted of numerous lower-tier cities, townships and villages. As an upper-tier municipal government, Metropolitan Toronto governed the development of key transportation infrastructure including the TTC subway line and Gardiner Expressway, and planned for rental and affordable housing. 
In 1996, the Greater Toronto Area Task Force released the "Golden Report" under the direction of the social democratic provincial government. The report recommended a more regional governance structure for the GTA with an upper-tier body while maintaining local municipal government as lower-tier (Lorinc 2011; Roger and Young, 2008). This move and recommendation were made to enable better coordination of services that spill across numerous municipalities such as transportation (Lorinc 2011; Kitchen 2002). However, the newly elected conservative provincial government went against this proposal as part of a neoliberal alignment of services and responsibilities and restructuring in Ontario (Boudreau, Keil, \& Young, 2009). Instead, the province amalgamated 6 municipalities of Metropolitan Toronto (Scarborough, York, North York, Etobicoke, East York and former Toronto) into a single-tier municipality City of Toronto.

Key services such as public transit and social housing were downloaded to local governments, which struggled to provide for these large urban complexities (Kitchen, 2002). Transportation strategies and plans remained largely fragmented and poorly coordinated. In order to address transportation at the regional scale, the province under the Liberal party established a special agency, The Greater Toronto Transportation Authority (GTAA), to coordinate transportation across the GTHA. This regional transportation agency was founded in 2006, and was rebranded into Metrolinx in 2007.

\section{Current Transportation Plans and Strategies}

\section{The Official Plan}

Toronto's Official Plan (OP) (City of Toronto, 2010) has already put in motion policies in favour of public transit. Special emphasis is made for a surface transit network - that gives priority and right-of-way to buses, streetcars and LRT. Policies also consist of integrating transportation with appropriate land use policies and design guidelines that enable transit-oriented development and smart growth. Policies to encourage mixed-use development along growth centres and avenues aim to make use of high-order transit corridors and infrastructure in order to connect people with a mix of employment, retailing, services and housing. 


\section{Zoning By-Laws}

While Toronto's Official Plan has put in motion transit-friendly policies and reurbanizing goals through housing intensification and mixed-use development, zoning by-laws to enable the transit-oriented development lag behind. Developers have to seek zoning amendments in order to develop mid-rise buildings in many places along the avenues. Another challenge is the assembly of land for intensification and mixed-use development alongside the lengthy process of securing zoning amendments for increased density. This issue is raised by current chief planner Jennifer Keesmat, who notes that zoning by-laws do not provide higher density at avenues as-of-right (as cited in Reid, 2013).

A major problem is that opposition to rezoning often comes from NIMBYism opposition by homeowners in the neighbourhoods (Levy 2013). Moreover, presently there is legislation under Section 37 of the Planning Act, which allows municipalities to extract capital funds and benefits from developers in exchange for granting them higher densities (OMMAH, 2010). Thus, by keeping densities low within zoning by-laws, City councillors and residents of a ward are able to secure funds and benefits from developers for neighbourhoods projects and amenities (Moore, 2012). In the absence of a regional governing body, there is then a large gap between land-use planning and transportation

planning (Lorinc, 2013). Mobility hubs identified by Metrolinx in its Big Move Plan that are designed to be centres of transit exchanges, employment, retail and housing do not necessarily have the municipal zoning requirements needed for the higher density mixedused development.

\section{Transit City Light Rail Transit}

The Transit City Light Rail Transit (LRT) Plan emerged in 2007 backed by thenMayor David Miller and approved by the TTC (TTC, 2007). The plan set in motion seven new LRT lines plus the replacement of Scarborough Rapid Transit line into a LRT line. The seven new LRT corridors consist of Sheppard East LRT, Etobicoke-Finch West LRT, Jane Street LRT, Eglinton-Crosstown LRT, Scarborough-Malvern LRT, Don Mills LRT, and Waterfront West LRT (as shown in Map 2.3 on the next page). 


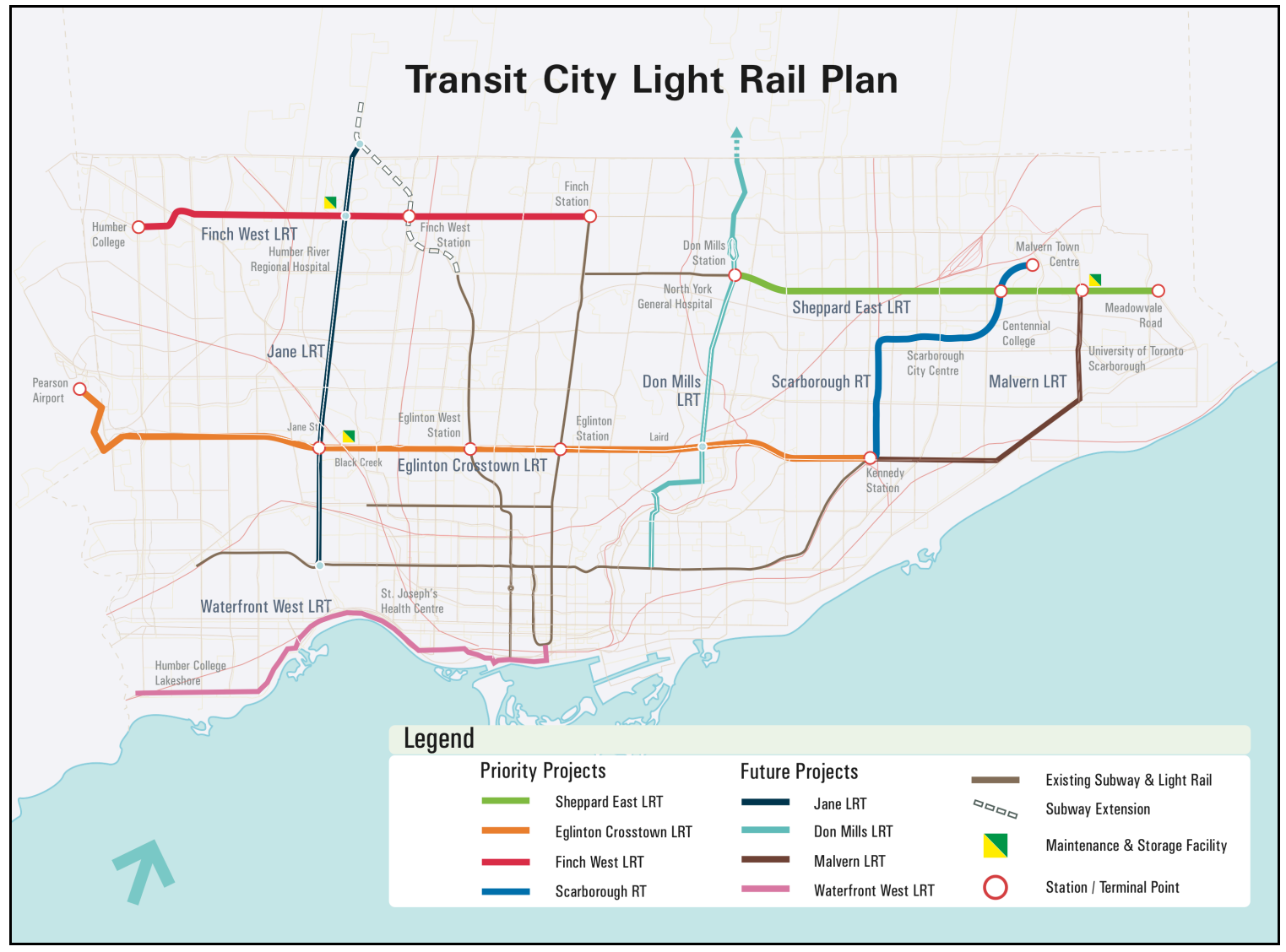

Completion of the Sheppard LRT was set as early as 2014, which would connect the Don Mills station on the Sheppard Line with Scarborough. However, the mayoral leadership shift in the 2010 led to delays in the construction process and an eruption of the streetcar versus car debate. This controversy arose when newly elected mayor Rob Ford opposed all surface transit and referred to Light Rail Transit as a "streetcar" that would interfere with automobile traffic and personal vehicles (Kalanowski and Rider, 2010). With the mayor pushing for the Sheppard subway extension instead of LRTs, construction at the corridor was halted and new studies were conducted. However, researchers such as Hulchanski underlined that multiple LRTs have big potential in creating connections with low-income neighbourhoods that Ford's subway line fails to address (Vincent, 2010). Though the Sheppard LRT was reinstated by City Council and TTC, the revised timeline sets the Sheppard LRT to resume construction in 2017 and finish in 2021 (Adler 2012). Likewise, construction on the Eglinton Crosstown LRT was halted until it could be finalized whether the LRT would operate at grade or underground. 


\section{Transit City Bus Network}

Another portion of the Transit City plan consists of a bus network that has received limited attention by media, politicians and public. Unlike the vast rail expansion project, plans for bus rapid transit are limited to a few corridors as seen in Map 2.4 below: Dundas Street West from Kipling Station to Mississauga; Yonge Street from Finch Station to Steeles Avenue; Kingston Road from Victoria Park Station to Eglinton Avenue East; Ellesmere Road from Scarborough Centre Station to Durham Region BRT. The bulk of the bus network improvements are envisioned through traffic signal priorities and queue-jump lanes at major intersections. In addition to bus service improvements, other items included provision of amenities such as vehicle arrival information, bus shelters and bus stop sign improvements. According to TTC (2009: p.36), of the 10,000 bus stops in Toronto, only 4,500 have bus shelters. TTC (2009: p.39) has proposed to install 75 new bus shelters between 2010-2014 - a number that is rather small in comparison to the capital investment in rail.

Another significant issue is that despite the vision to improve bus service and network in Toronto, service cuts were announced in late 2011 and were implemented in 2012 following Mayor Ford's cuts to operating budgets (Rider \& Kennedy, 2011; CBC News 2011). This caused reduction to weekend and night hours that may have a particular bearing on transit-depending communities.

Map 2.4 Plan for Bus Rapid Transit in Toronto (Source: TTC, 2009)

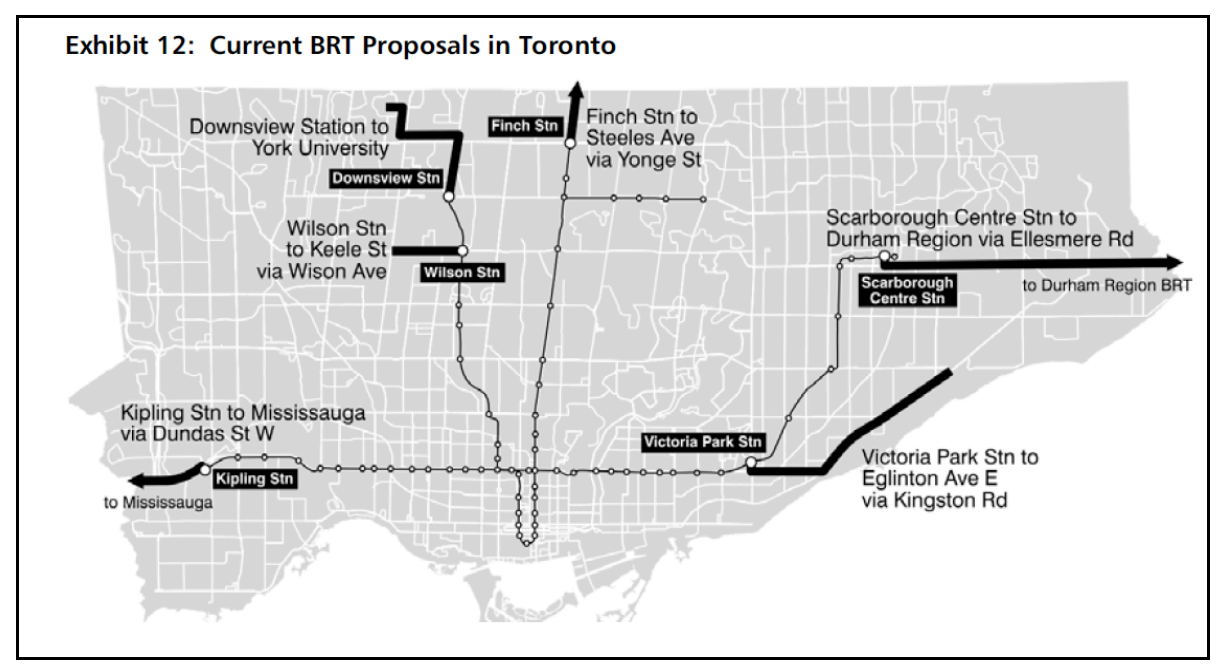




\section{MoveOntario 2020}

Much of the current impetus in transit development comes from provincial government's action plan MoveOntario 2020 that aimed to invest in rapid transit. Released in 2007, it sets to provide financial backing of $\$ 11.5$ billion to 52 rapid transit projects across the GTHA (Ontario, 2007). The primary vision behind this action plan is to cut down on greenhouse gas emissions and to promote economic development in the region. $\$ 8.4$ billion in provincial grants were promised for Toronto's LRT projects, at the time Transit City, championed by then Mayor David Miller (Ontario, 2007).

However, the provincial funding was scaled back in 2010 and Metrolinx rephased the LRT projects (Goddard, Rider \& Kalanowski 2010; Metrolinx 2010). The EglintonScarborough LRT, dubbed The Crosstown, is now broken down into two phases, with the western segment from Black Creek Drive to the airport to be constructed in phase 2 . Likewise, completion of Sheppard LRT is delayed until 2021.

\section{The Big Move}

MoveOntario's vision was succeeded by a comprehensive plan, The Big Move, in 2008 by Metrolinx - the regional transportation authority established by Province of Ontario to oversee the coordination and execution of transportation expansion in the region. The plan puts forth a $\$ 50$ billion investment and capital project plan in transportation infrastructure and expansion over 25 years in the Greater Toronto and Hamilton Area (GTHA) (Metrolinx, 2008). The regional plan is coordinated by Metrolinx with the bulk of the transportation proposal focusing on rapid transit. The Big Move absorbed Toronto's LRT projects, which will now be coordinated by Metrolinx with the partnership of TTC and City of Toronto. The 5 in 10 Plan determined by Metrolinx sets to complete 5 projects in 10 years, that is, by 2021 (Metrolinx, 2010). Of these five priority projects, four are Toronto's LRT projects (the fifth project is York's Viva BRT outside the scope of this paper) as seen in Map 2.5 on the next page. 
Map 2.5 Approved Phase 1 of LRT lines under Metrolinx's 5 in 10 Plan $^{1}$ (Source, City of Toronto, 2010)

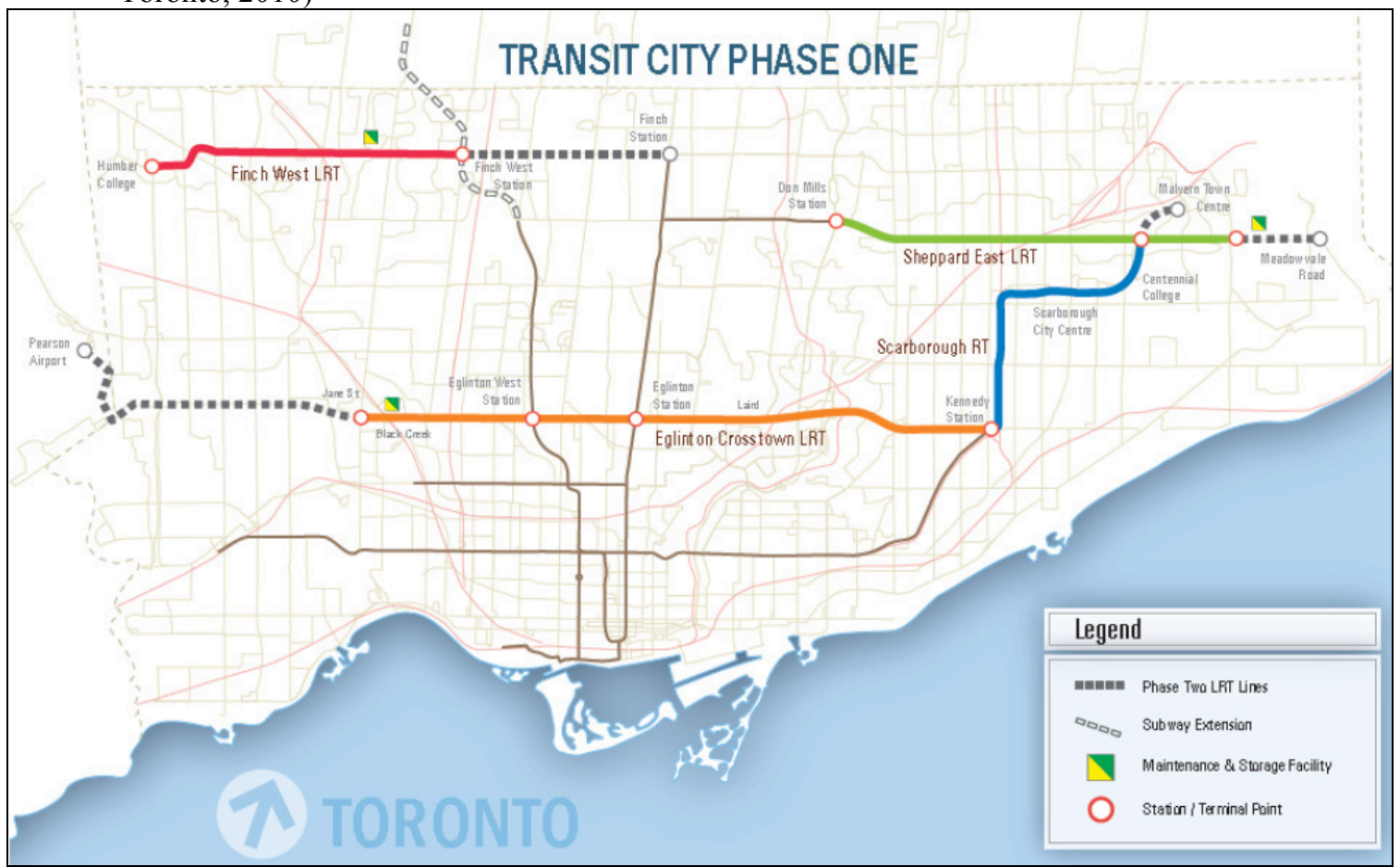

However, the challenge for Metrolinx and The Big Move is that it has no reliable and guaranteed revenue stream, lacks full governing authority and is not a democratically elected body (Lorinc, 2011). While a few of the projects have provincial funding, the majority of The Big Move plan lacks capital. Metrolinx is tasked with preparing a strategy for generating revenue that includes possible new taxes such as toll roads, congestion charges, fuel tax, regional income tax and regional sales tax. This revenue generating strategy is marked for discussion and decision by the province of Ontario in 2013.

The transportation plans outlined in this chapter provide the context within which my research is set. In the next chapter, I will look at the existing literature, studies, and bodies of knowledge regarding immigrants and transportation in Toronto.

\footnotetext{
1 This general map does not show which segments of the LRT lines are tunneled, at-grade or elevated. For these details, please consult the TTC and Metrolinx websites
} 


\section{CHAPTER 3 - ENVIRONMENTAL JUSTICE FRAMEWORK AND LITERATURE REVIEW}

\section{Social Exclusion in Transportation}

Much of the literature on transportation planning, social inequities and social exclusion has been dominated by debates on the spatial mismatch hypothesis (Bauder, 2000; Blumenberg and Manville, 2004). The Spatial Mismatch Hypothesis ascribes unemployment and poverty to spatial disconnects in the housing and employment locations of low-income inner city populations. The theory of spatial mismatch goes back to John Kain (1968), who primarily concerns himself with the large spatial distance between jobs and housing as the reason behind growing inner city unemployment and poverty. This large spatial distance subsequently becomes a transportation problem. The post-industrial shift in job opportunities from inner city to suburban locations and "edge cities" meant inner city urban poor were unable to access employment.

Later studies went beyond Kain's focus on the spatial distance between housing and employment and instead turned their attention to transportation barriers such as lack of car ownership and absence of transit routes (Blumenberg and Manville, 2004; Cervero, Sandoval \& Landis, 2002). The literature is divided on what are the best transportation solutions to the problem of job inaccessibility. Some of these studies recommend better access to a personal vehicle as the most efficient way of increasing job opportunities rather than public transit reverse commute programs (Blumenberg and Manville, 2004; Cervero, Sandoval \& Landis, 2002; Blumenberg, 2004). The applicability of the spatial mismatch hypothesis and other transportation policies that emphasize transportation barriers in the Canadian context has not been fully tested. However, researchers such as $\mathrm{Hu}$ and Giuliano (2006) shift our understanding of spatial mismatch beyond the frame of the urban poor in the inner city. While acknowledging that there may still be a disconnect between housing and jobs in their Los Angeles case study, they highlight that lowerincome communities are increasingly living in inner suburb rings rather than in the city core. 
However, the exclusive emphasis on access to job opportunities and spatial disconnect between home and work disguises other issues that relate to transportation and the built environment, such as health risks and social inequalities themselves. The recent report Toward Healthier Apartment Neighbourhood (2012) found that health outcomes are poorer in areas characterized by post-war apartment buildings and poor walkability in Toronto. This research notes that inhabitants of apartments in the inner suburbs "have lower incomes, experience higher rates of diabetes, have less access to fresh food, live in less walkable neighbourhoods, and are more vulnerable to extreme heat than other residents in Toronto" (Public Health 2012: 3). As part of the report's policy recommendations, better transit connectivity and design walkability are identified as strategies that can promote healthier neighbourhoods. Given the multiplicity of issues, there is a need for a theoretical foundation. One theory in transportation planning put forth by Preston and Ragé (2007) explains social exclusion in transportation as a result of the lack of accessibility to transportation services. The authors note that "too much private mobility can contribute to social exclusion through environmental degradation, adverse public health impacts, high accident rates, declining public transport, changes in land use and community severance" (Preston and Ragé 2007: 154). As a result, the theorists call for an accessibility approach, which looks at ease of reaching rather than ease of moving.

This theoretical model is inviting but does not does not fully address some of the structural factors such as housing discrimination and transit underinvestment that shape the built environment and give rise to these social exclusions and lack of accessibility in the first place. A more interdisciplinary body of literature dealing with concerns of inequality, structural and social exclusion and risks in transportation is the environmental justice and transportation justice literature.

\section{Environmental Justice}

The environmental justice approach raises issues of spatial inequities facing racialized and poor communities due to unfavourable urban and regional development and policies. In particular, the dominant environmental justice perspective tackles 
whether environmental risks are concentrated for particular groups of people and their locations through discriminatory land-use planning and how to prevent it (Bullard, 2005: 25). Enviornmental justice frameworks also question whether there are equitable distributions of enviornmental goods. In addition to spatial inequalities, environmental justice points to procedural inequalities where minorities lack capacity to participate in the decision-making processes of policy and land-use development (Gosine \& Teelucksingh, 2008: 17-18). In contrast, middle-class, educated and white people as members of dominant groups are generally able to protect their interests through stakeholder participation and direct undesirable industries away from their neighbourhoods while gaining desirable resources and services.

Though environmental justice analyses initially focused on the concentration of toxic facilities and environmental risks, the framework has evolved and been adapted to include transportation inequities and service provisions (Bullard \& Johnson, 1997; Bullard, Johnson, \& Torres, 2009; Chen, 2004). Thus, environmental racialization and injustices not only manifest in the overrepresentation of toxic and harmful facilities in racialized neighbourhoods but also in the underrepresentation and poor accessibility of key urban amenities and facilities - particularly public transit. Additionally, emerging literature has expanded and reconceptualized environmental justice as not simply a distribution problem, but rather that of structural issues that produce spatialized social inequities (Teelucksingh 2007; Stanley 2009). My study on transportation planning in Toronto and the links to immigrants examines environmental justice from this latter conceptualization.

Applications of the environmental justice framework to transportation-related concerns have so far been mainly explored in the United States. Specifically, transit justice highlights various transportation-related equity issues facing the urban poor in major American cities such as Los Angeles (Bullard, Johnson \& Torres, 2009; Bullard \& Johnson, 1997). The literature highlights the historical under-investment in rapid transit services for racialized populations. It also points to the environmental risks facing poorer communities that are living along highway corridors. In the context of U.S., Robert Bullard emphasizes that transportation racism is not just a system of racist transit 
planning policies that favour rich white suburbanites at the expense of inner-city poor communities; it also determines where low-income people of colour communities "can live, work and play" (Bullard, 2009: 20). In discussing the various aspects of injustices, Bullard and Johnson (1998: 2) outline three facets of transportation inequities: procedural, geographic and social inequities. Procedural inequity points to the fact that decisions are often made with limited input and accountability to certain groups of people - often low-income immigrant and racialized groups. Geographic and spatial inequities suggest that transportation projects favour particular regions, for example by investing in commuter rail from suburbs to CBD over inner-city bus networks. Finally, the social inequity facet looks into how benefits and amenities of transportation project may favour privileged groups while the burden is placed on minorities.

An important consideration when using an environmental justice framework is the different spatial trends of Canadian cities from United States. Some scholars have applied this approach to the Canadian context while also outlining the need to ground environmental justice in its local context (Gosine \& Teelucksingh, 2008; Debbane \& Keil, 2004; Teelucksingh 2002). Gosine and Teelucksingh (2008) emphasize that even though Canadian cities may not display the same high levels of ghettoization as cities in the U.S., racialization of low-income areas still exists in Canadian urban regions. These racialized inequalities further hide behind discourses of multiculturalism. As a result, environmental inequalities go unnamed. The authors call on researchers of environmental racialization to pay attention to the nuanced patterns of gender, race, class and immigrant status in cities in Canada, and to the ways in which racialized spaces are reproduced through political, economic and structural processes. In this context, I make use of Teelucksingh's criticism of dominant trends in the environmental justice literature that describe spatiality as fixed rather than dynamic (Teelucksingh, 2002: 121).

Teelucksingh's dynamic approach to spatiality is particular useful in understanding the demographic changes discussed in this paper and how it relates to planning. Likewise, this growing body of literature in Canada has widened the reach and conceptualization of environmental justice and racialization - looking at issues of injustices in the 
environment as part of a social structure rather than a problem of liberal distribution (Debanne and Keil 2004; Teelucksingh 2007; Stanley 2009). ${ }^{2}$

This expanded framework and conceptualization of environmental justice can provide a comprehensive understanding of transit, spatiality and housing locations for vulnerable population, and overcome the limitations of the spatial mismatch hypothesis and other theories of social exclusion in transportation. Next, I review the literature on immigrants' use of public transit in Toronto and their transportation barriers.

\section{$\underline{\text { Immigrants and Transportation }}$}

The outlined theoretical framework is especially beneficial for our understanding of racialized immigrants and transportation. The planning literature in this area is extremely limited. Only a few studies have specifically centered a discussion of immigrants' use of transit (Heisz and Schellenberg, 2004; Thomas, 2011; Lo, Shalaby \& Alshalalfah, 2011). The Heisz and Schellenberg (2004) study, based on micro data from the 2001 Canadian Census, found that there was a strong positive relationship between the number of recent immigrants (those that arrived within the past 10 years of the census survey) and the use of public transportation in Toronto, Vancouver and Montreal's CMAs. In Toronto, $36.3 \%$ of immigrants use public transit for work compared to $20.7 \%$ Canadian-born (Heisz and Schellenberg 2004: 172-173). The findings of the regression analysis further showed that regardless of age, household income and distance to work, recent immigrants are more likely to use public transit. In a case study of Filipino immigrants in Toronto, Thomas (2011) points out the increasing difficulty of immigrants to afford housing near rapid transit areas. However, the researcher notes that Filipino immigrants, in most cases preferred to live close to public transit and housing choice was primarily a factor of affordability (Thomas 2011: 146-147).

\footnotetext{
2 Further research might explore how an environmental justice approach can be put in conversation with the political economy literature on urban governance. Toronto-based studies have explored how transportation models are shaped by various urban governance paradigms and discourses, such as climate change and global city competitiveness (Boudreau, Keil and Young, 2009; Keil and Young, 2008).
} 
An emerging set of research conducted at CERIS Metropolis Centre and at the Cities Centre - though focused on housing, employment and settlement trends - raise important transit trends and concerns (Basu 2013; Hulchanski 2010). Basu's report on newcomers in Scarborough highlights public transit as the dominant problem that study respondents felt was essential for improvement. The study pointed to many issues of inaccessibility with transit, particularly with high fares, lack of access for people with disabilities and children, poor connectivity, and infrequent service (Basu 2013: 22-23). The Three Cities in Toronto report highlights that the spatial proportion of transit use of people living in City \#3 (34\%) is similar to, and in fact a little higher than City \#1 (30\%) despite having less public transit (Hulchanski, 2010: 23). In other words, one can infer that despite having limited access to public transit in the inner suburbs, residents in City \#3 - predominately low-income immigrants - continue to use public transit as a means to get to work. Another report on walkability in high-rise apartment neighbourhoods in Toronto also found that most residents relied on public transit for travel and did not own cars (Hess and Farrow, 2011: 2).

Nevertheless, in City \#3, 63\% of the population travels to work by car whereas only $54 \%$ of population in City \#1 travels by car. This difference can partially be attributed to the built urban form; the inner city is more walkable and bicycle friendly while the built form of suburban Toronto is more autocentric. Car use involves high costs, such as fuel, repair and insurance that can take away from the household budget. Moreover, household ownership of a vehicle is highly gendered (Law, 1999). One GTAbased study assessing the expenditures in housing and travel across the GTA found that cost in housing and travel systematically increased as one moved away from the city (Miller et al, 2004). The researchers note that this affects low-income communities, since the decreasing stock of affordable housing in the city may force poorer households to rent in the peripheries. As a result, they are forced to shoulder the high costs of car use:

[L]ow-income households may be forced to live in suburban locations if these are the only places in which affordable housing exists. Those households may, however, then be required to spend a considerable portion of their income on auto-based transportation with little money left for other necessities. Again, an alternative distribution of affordable housing that resulted in less costly travel patterns for such households would be highly desirable. (Miller et al, 2004: 191). 


\section{Gender and Transportation}

There is wide body of literature that has looked at women and gender in transportation planning - often pointing out that women's travel patterns consist of multiple short trips that may not be related to work (Kwan 1999; Blumenberg 2003; Law 1999). Many studies show that women's experiences of transportation are often shaped by a gender division of labour, which can involve multiple errands such as childcare, grocery or shopping trips (Law 1999; Khosla 2005). Literature is divided on whether transit policies should enable automobile access or better public transit. Blumenberg (2004) calls for transportation policies that encourage automobile use and access to a vehicle as a way for low-income women to do multiple errands and shorts trips while navigating to work. Blumenberg's study problematizes the conventional Spatial Mismatch Hypothesis by emphasizing that low-income women in American cities are more likely to work closer to home. The research goes on to argue that cars allow lowincome women to manage multiple short trips and access jobs more easily during periods of flexible, part-time work or when job searching. However, these studies are based in United States and may not have the best policy applicability in the Canadian context where settlement patterns are different.

In Toronto, transit use amongst immigrants is highly gendered with immigrant women more likely to use public transit to work than immigrant men. Based on 2001 census, $44.8 \%$ percent of immigrant women used public transportation to go to work compared to $28.2 \%$ immigrant men (Heisz and Schellenberg 2004: 175). In Toronto, one study also points to safety concerns for women and how the stop request program, designated waiting areas and other gender equities measures in TTC employment came about through feminist lobbying (Wekerle, 2005). Presently, the scholarly literature on current immigrant women's transit experiences, accessibility and barriers in Canada is limited.

Community-based reports have attempted to address some of the scholarly gaps in the literature of low-income immigrant women and transit in Canada (Koshla 2003; BRU 2005). One report titled If Low-income women counted in Toronto by Punam Khosla (2003), though not focused on transportation, brings to attention the particular barriers 
affecting women when accessing transit. Khosla employed an action-based research methodology based on participatory and community organizing, which involved a number of meetings and sessions in conjunction with partner organizations in different neighbourhoods. The sessions brought in over 150 low-income and immigrant women throughout Toronto. Issues highlighted include the affordability of rising TTC fares, as well as poor servicing and long bus rides in the regions of Scarborough and North York.

Since focused research on immigrant women and transit in Toronto is limited, a case study from Vancouver by the Bus Riders' Union (BRU 2005; Khan 2008) can shed some perspective on immigrant women's travel challenges and the connections to labour and housing market. Having been host to Winter Olympics in 2010, Vancouver saw wide rail investment in recent years. The participatory action research on transit and environmental justice specifically documents the stories of women, many of whom are immigrant women working in the flexible labour industry. The report raises important questions including how immigrant women afford transit, get to work and walk long distances during flexible or night shifts. In another study based in Vancouver, BRU (n.d.: 22) notes that "immigrants and refugees, First Nations people, and other people of colour are significantly over-represented among transit-dependent people". This study also raises concerns about the disinvestment in the night buses of Vancouver and the shift to new rail projects that rarely benefit immigrant women:

In our transit system, there is a clear pattern of unequal allocation of transit funds away from the needs of transit dependent communities and into privatization projects. Even though eighty percent of transit users depend on buses exclusively, the bus system is consistently cut and under funded at the same time as massive spending goes to Skytrain, which only six percent of transit users rely on exclusively (BRU, n.d.: 22).

In conclusion, the literature has pointed to stark gender and racialized inequalities in transportation use and accessibility. My next chapter will outline my rationale in selecting qualitative interviews in order to understand the depth of transit barriers and environmental risks facing immigrants. 


\section{CHAPTER 4 - METHODS AND STUDY DESIGN}

\section{Methodology}

Transportation planning and travel demand management has conventionally relied on mechanistic and technical steps based on statistical modeling and engineering solutions (Rodrigue, 2006). However, while this approach is often used for predicting and simulating travel patterns for work-based trips, it does not provide the information needed in order to understand travel behaviour and choices across and within various groups. Commenting on some of the limitations of current survey instruments, transportation planner Eric Miller (1999) calls for more comprehensive data collection within Toronto. Miller also notes that the urban region is currently facing unique demographic trends, with an aging baby boom population, a young baby boom echo generation, and immigrants - each with different travel patterns, needs and demands (Miller, 1999: 18). Another major challenge in Statistics Canada census data is that information collected on transportation is based on mode of travel to work only. As a result, there is limited scope to investigate the gendered aspects of traveling.

Another data source used for transportation analysis and modeling is the Transportation Tomorrow Survey. The survey is sponsored by the Ministry of Transportation Ontario and has been carried out every 5 years by local government and transit agencies in Southern Ontario since 1986 (Data Management Group - U of T, n.d.). While the survey instrument collects more thorough information on the various forms of trips, the survey does not collect information on whether households have immigrated to Toronto recently. The lack of comprehensive data on socio-economic background in the Transportation Tomorrow Survey thus makes it difficult to address the complexities of the Toronto urban region with regard to new patterns of immigrant settlements.

Some scholars examining transportation behaviour in Toronto with immigrants or low-income populations have begun to use qualitative methods, such as interviews, focus groups, mapping exercises (Thomas 2011; Hess and Farrow 2011). Qualitative interviews with immigrants can address the methodological shortcomings and better understand 
complex travel issues and phenomena that are often missed by transportation engineers and planners. For example, Ren Thomas's (2011) mixed-methods case study included 32 qualitative interviews with 32 Filipino immigrants (12 male and 20 female) in the Toronto CMA. Participants were recruited through community, faith-based and advocacy organizations as well as social networks and were interviewed on their housing and transportation choices. Several studies on immigrants in Toronto further used snowballing through social and community networks with regard to research on housing choices and preferences (Agrawal 2006; Ghosh 2008). The snowballing method with immigrant groups can address the shortcomings of their limited representation in surveybased research and thus enable an expanded body of knowledge on how immigrants are making transportation-related decisions and what factors influence their choices.

Based on these insights, I decided to do in-depth qualitative interviews with nine immigrants in Toronto, whom I recruited through snowballing and interviewed between February and March 2013. In the interviews, I sought to explore immigrants' own experiences and choices of public transportation, barriers they may encounter and other forces that influence their transit accessibility.

\section{$\underline{\text { Research Method }}$}

My initial contact with potential participants was through organizations and frontline workers that primarily serve immigrants and women in the inner suburbs. However, the limited timeline of this major research project made recruitment through community groups difficult, as organizations tend to have their own research approval protocol. Furthermore, my lack of personal connection with some of the contacted professional organizations meant that their commitment to and interest in this graduate research process was limited.

I then recruited through my own social networks and through an immigration and art project of South Asians in Canada that I previously participated in. I combined this with snowballing. The result of these recruitment strategies has been that most participants - six out of nine - were from South Asia. Recruiting members of a 
community project that took place in downtown Toronto further meant that some of my interviewees had fairly good access to downtown area of Toronto and TTC subway lines.

Though it was difficult to recruit in such a limited time, I received a lot of interest among people who wanted to be part of this transportation study. Through my social networks and snowballing, several people living in Mississauga and Brampton who commute to Toronto for work expressed a keen interest to participate and share their transit experiences. They were excited as they have rarely been part of a transportation discussion before. However, the scope of the study was specifically targeting residents of Toronto. The formal written consent process also at times deterred interested candidates who were more interested in having a dialogue than having to deal with the formality of written forms. Another key challenge in conducting interviews were transportation barriers themselves, especially with immigrant women. Economic factors also presented a barrier to participation. Many times, candidates were juggling work shifts, job searching, child-rearing, care-giving for family and being out of town for family visits. In order to enable these individuals to participate, two out of the nine interviews were conducted over the phone. The remainder took place in gurdwaras (a Sikh temple), coffeeshops and apartments, which participants found most convenient and compatible with their duties of child-rearing and community faith service.

The interviews consisted of open-ended questions based on an interview guide (see appendix A) that was designed to encourage participants to share their decisionmaking process with transportation choices and barriers. This allowed them to share how they negotiate between their mode choice and housing location, and what they may be forced to compromise or trade off in the process. Socio-demographic characteristics, such as age range, year immigrated, income range, were collected in order to situate their perspectives and travel experiences, choices and accessibility concerns. Information gathered was confidential, identifiable characteristics were not collected and pseudonyms were used. At times, individuals shared their knowledge and transportation experiences of their household members and families. However, interviews were only conducted with individuals and not with households. In the analysis, I have attempted to lay open which accounts are first and which second hand. 


\section{$\underline{\text { Participant Demographics }}$}

Of the nine participants, seven were immigrant women. All participants had immigrated to Canada only within the past 16 years. Most of them were low-income and earning less than $\$ 30,000$ annually. Three participants lived in single-person households. The remaining were living with family members, including siblings, spouses, parents and children. With the exception of one condominium owner, all participants were tenants who rented their dwelling units. Seven of the participants lived in high-rises, one in a detached house and one in a mid-rise loft. Only two of the participants had a driver's license and had access to a household car.

Table 4.1 Participant Demographic Characteristics

\begin{tabular}{|c|c|c|c|c|c|c|c|}
\hline Pseudonym & Age & Tenure & $\begin{array}{l}\text { House- } \\
\text { hold } \\
\text { Size }\end{array}$ & Intersection & $\begin{array}{l}\text { Neighbour } \\
\text {-hood }\end{array}$ & $\begin{array}{l}\text { Year } \\
\text { Arrived }\end{array}$ & $\begin{array}{l}\text { Country of } \\
\text { Origin }\end{array}$ \\
\hline Selina & $20 \mathrm{~s}$ & Rental & 2 & $\begin{array}{l}\text { Yonge- } \\
\text { Eglinton }\end{array}$ & Midtown & 1998 & Bangladesh \\
\hline Geeta & $50 \mathrm{~s}$ & Rental & 2 & $\begin{array}{l}\text { Islington- } \\
\text { Finch }\end{array}$ & Rexdale & 1998 & India \\
\hline Mani & $30 \mathrm{~s}$ & Rental & 1 & $\begin{array}{l}\text { Bloor- } \\
\text { Sherbourne }\end{array}$ & $\begin{array}{l}\text { St. James } \\
\text { Town }\end{array}$ & 1997 & Trinidad \\
\hline Elena & $40 s$ & Rental & 1 & $\begin{array}{l}\text { Queen- } \\
\text { Bathurst }\end{array}$ & Niagara & 2011 & India \\
\hline Maya & $30 \mathrm{~s}$ & Rental & 2 & $\begin{array}{l}\text { Don Mills- } \\
\text { Overlea }\end{array}$ & $\begin{array}{l}\text { Thorncliffe } \\
\text { Park }\end{array}$ & 2011 & India \\
\hline John & $50 \mathrm{~s}$ & Rental & 2 & $\begin{array}{l}\text { Bloor- } \\
\text { Sherbourne }\end{array}$ & $\begin{array}{l}\text { St. James } \\
\text { Town }\end{array}$ & 2001 & Trinidad \\
\hline Eve & $20 \mathrm{~s}$ & $\begin{array}{l}\text { Condo } \\
\text { minium } \\
\text { Owner }\end{array}$ & 4 & $\begin{array}{l}\text { Jane- } \\
\text { Eglinton }\end{array}$ & Mt. Denis & 2007 & Vietnam \\
\hline Moses & $50 \mathrm{~s}$ & Rental & 1 & $\begin{array}{l}\text { River- } \\
\text { Dundas }\end{array}$ & $\begin{array}{l}\text { Regent } \\
\text { Park }\end{array}$ & 2008 & Jamaica \\
\hline Ameena & $20 \mathrm{~s}$ & Rental & 4 & McLevin- & Malvern & 2000 & Sri Lanka \\
\hline
\end{tabular}




\section{CHAPTER 5 - INTERVIEW ANALYSIS}

\section{$\underline{\text { Themes }}$}

A number of themes emerged from my interviews with immigrants living in the inner suburbs and core of Toronto. Many of the participants noted that they relied heavily on transit as they lacked access to a car or even a driver's license. Hence, they depended on transit or walking for all activities and so were often impacted by poor service especially during weekends and night. Moreover, lack of accessibility of transit and a built environment not conducive to walking were particularly challenging for immigrant women, families with children, and seniors. Gendered aspects of transportation such as travelling with children or groceries on public transit were often cited as a key barrier. Cost was perhaps the biggest challenge for immigrant participants with regard to transit. Amongst the transit service problems, infrequent, poor and unreliable service were mentioned as key areas of concerns for many participants. Lack and absence of bus shelters were also significant. In the following sections, I analyze these thematic findings one by one, followed by a discussion of their relevance to this study.

\section{Public Transit Usage and Dependence}

Almost all the participants used transit for all their activities. Some participants volunteered the information that they are fully dependent on public transportation in the city, without me having to prompt them. As one interviewee who chose the name Selina for this study put it: "Yeah, I am dependent on public transport at this point, though."3 Similarly, Geeta stated: "I totally depend on transportation”. Another participant, Elena also used the word dependent readily to describe her travel routine: "I use the TTC mostly, the streetcar, the subway and the bus to reach my place of work. I am heavily dependent on that. I use it rather extensively". These accounts suggest that many

\footnotetext{
3 All of these interviews were conducted by me in person in February and March 2013. I will here simply refer to interviewees by the pseudonyms they chose for themselves.
} 
participants embraced a particular to relationship to public transportation. This also shaped their identity as their sense of mobility is closely connected to their levels of access of to public transit. One participant, Mani, further emphasized that he used public transportation for trips to large department stores: "I use transportation in Toronto to get to work, to and from work. And I use transportation for personal stuff, socializing and buying household items, from Walmart and Canadian Tire”.

In some cases, participants used active transportation - walking - as a way of getting around high fares or inaccessible transit, particularly for their grocery shopping. None of the participants mentioned bicycling as a mode of their choice. Only two of the nine households had access to a car. In these households, the mother in the family used the car while the remaining members used public transit as their primary means of travel to work and school. In these households, the car was a convenient and preferred way to do grocery shopping in particular.

As my participants were largely transit-dependent, numerous challenges arose with housing choice, work opportunities, cost and transit problems that I discuss next.

\section{$\underline{\text { Housing and Transportation }}$}

My study confirms that housing choice and access to transportation are strongly linked. Affordability stood out as the key determinant of housing, which then influenced how near respondents were able to live to rapid transit, what were their travel patterns, and what transportation-related challenges they faced. Most interviewees noted that they had limited choice in terms of where they could live. Many chose to live in Etobicoke or Scarborough in order to best afford rent. Eve argued that it was difficult for a family to rent and own a home downtown. In order to afford a place that is a decent size for her family, she moved to the Mt. Denis neighbourhood at Jane-Eglinton, even though it is further away from the subway line, from her workplace, as well as her from her husband's workplace:

"Close to the subway is more expensive...rent or buy, doesn't matter. It is more expensive, and the fees are more too I think [discusses fees and amenities]. And 
it's small. Downtown is usually for single or couple professionals, right? But for family, with kids, it is not really ideal. Yeah, the apartment is really small. There is no room for them to run around, or storage." ${ }^{4}$ (Eve)

For participants who chose to live along the subway and in downtown Toronto, there were very few areas that they could afford. Two of the participants had recently moved from the inner suburbs to St. James Town. In both cases, the affordability of St. James Town was the deciding factor. Mani also emphasized that St. James Town was not his first choice as he preferred to live on the west side of town along the Bloor-Danforth line which was closer to his work. However, the higher cost of rent and housing meant that he had to settle in St. James Town since it was the only downtown location on the subway line that he could afford:

"It wasn't my first choice to be at Bloor and Sherbourne. I wanted to be closer to Bloor and Dufferin Area, closer to Dufferin Mall, the West side, closer to my work. I couldn't afford the apartments and the places there". (Mani)

In addition to the affordable options of housing that St. James Town offers, familiarity of the neighbourhood was a deciding factor for John:

"[W]e looked at other places downtown, but then we compared here to other places, we realized here was the best place. We knew here already, and it was easy to talk to the superintendent cause he knew us from before, so, here was the natural choice to come back." (John)

Participants who lived further away from rapid transit would attempt to live as closely as possible to bus stops in order to have better access to public transportation. After housing affordability, proximity to transit was often the next determinant for housing choice for most participants. As Ameena highlighted, her flat "[i]]s still accessible by TTC in case we need to go somewhere". Moreover, Maya commented on her partner's housing choice, "because she also doesn't drive, she obviously selected a place that was accessible to transportation".

In some instances, interviewees argued that being connected to particular kinds of amenities, for example places of worship and grocery stores selling ethnic food, was

\footnotetext{
${ }^{4}$ I chose to preserve my interviewees' natural speech as it reflects the plurality of immigrant accounts included in this sample.
} 
important to the location they or the decision-making member in the household had chosen. Maya, who lived in Thorncliffe Park, outlined various reasons for choosing the area in addition to its affordability: "[My partner] chose it because it is a big South Asian immigrant community, and there is a lot of grocery stores that have South Asian like spices and food and it is affordable". Likewise, Ameena, who lives in the Scarborough area of Malvern, highlighted the strong social network of this neighbourhood:

"[W]e also have a lot of friends and family around here. And it's close also to a religious community that would be, it's good for organization and the mosque we go. So it is convenient for us cause all the amenities we look for are close by". (Ameena)

Maya's and Ameena's accounts suggest that participants are actively renegotiating their choices and different ways to overcome transportation-related barriers. While their neighbourhoods of Thorncliffe Park and Scarborough are not within the vicinity of rapid transit, their location provides them with better access to diasporic amenities that a more central location along the subway line might preclude.

Furthermore, barriers to mobility were often directly linked to settlement-related barriers that limited immigrants' freedom, and independence. Settling in, in the form of finding a job and housing, can be a lengthy process for immigrants, including people in this sample. In addition to this, waiting for immigration paperwork to come through, or for degrees to be certified, can take up considerable time, during which one cannot work. This affects how much one can afford to pay rent, and hence where one can live. It thereby also shapes one's transportation-related experiences and barriers. As Maya points out, "we were on one income for a long time, because of my immigration paperwork and so it had to be something that we could afford on one income". Similarly, John notes that he had to move to Scarborough even though it was far from his work because family members provided a lot of initial support for his settlement:

"When we first got there, we were living with my sister. She was moving, so we have to move too [...] When we got settled in and got a little more independent, we decided that it made sense to come back downtown to save money". (John)

The interviewees' accounts thus also bring to light the need to think about transportation holistically, and to reconceptualize transit barriers as always already inter-connected with 
other kinds of barriers, such as immigration, housing, employment, and access to life chances more generally. The next section explores this in greater detail.

\section{Transit and Work Opportunities}

A number of participants linked their challenges in securing desirable work and job opportunities with their experiences of public transit in Toronto. The lack of an extensive rapid transit network, long commuting times and poor integration and connectivity for newcomers within the Greater Toronto Area often presented barriers to job seekers. For example, Selina described the difficulties she faced when travelling to a job interview after a long commute from Toronto to an unfamiliar location in the York region:

"Inner city bus is planned for every 5 minutes or every 10 minutes. Over there, it was every 30 minutes or every 45 minutes. Waiting for the bus takes longer than the actual commute. It was really draining. When I went to the interview, I got really drained." (Selina)

Several participants shared that it was difficult to use transit to get to work outside of Toronto in the GTA and so they decided to settle for a different job. Selina shared how she "didn't take that job just because of the transportation issue. It would have been a good job, but I knew I would not enjoy the commute". Likewise, Geeta had turned down offers from work that were located outside of Toronto in the GTA: "I had been to Oakville, I had been to Ajax. I had lots of offers from schools there. But they were too far, so I didn't accept the offers there. I got a job in (Toronto), so I was happy." According to Selina, barriers to public transit are particularly significant for immigrants who are just starting their careers: "When I look back at it, I am like that job would have gotten me in places. Now, in retrospect, I am like why didn't I take it". She went on to share that the job salary was so low that it didn't give her the option to temporarily relocate either.

Another challenge to job hunting were the high fares of transit. Many participants shared their difficulties in using public transit when they were searching for employment 
as they could not afford to buy the fares. John would buy day passes specifically to look for jobs on certain days:

"Initially when I first got here, I would use the day pass, but that was generally looking for work. You know, I couldn't afford to have a metro pass, you know? I would use the day pass for looking for work, getting around, just going about". (John)

Furthermore, some participants noted that they cannot qualify for job opportunities as job listings expect them to have a driving license and have access to a car: “... a lot of jobs that I look at, they ask for like having a license and stuff” (Maya). The next section discusses the issue of cars and driving licenses for immigrants in greater detail that confirm why immigrants may depend on public transit more.

\section{Cars and Driving Licenses}

Several respondents had poor mobility in the city because they did not have a driver's license. Learning to drive a car presents particular hurdles for immigrants, who often juggle multiple obligations and activities. Eve shared that she "was working, going to school, and also taking lessons, so it was pretty busy". Maya, who was navigating the process of learning how to drive and getting a license at the time of the interview, argued that "it's a process, right? It seems you have to get like different levels of licenses and stuff like that. So, every summer I think I'm going to do it, and it hasn't happened yet."

For people who immigrated to Canada in their teens, not having the opportunity to learn how to drive was compounded by the fact that their Canadian-born peers had better opportunities to get their licenses in high schools. Mani shares his experience of settling in Canada and school and missing out on the automobile learning stage:

"I moved to Canada when I was 16, almost 17 and that is the age when everybody gets their license, it is a big deal, it is a transition to adulthood. But for me, that wasn't the priority. It was more settling in Canada, settling in high school, figuring out my life here... [discusses transit to school] Also, it had to do with I guess having access to a car, to drive. Because even if I got my license, I wouldn't have a car anyway. It is a cost thing. We only had one car and my dad would use it for work." (Mani) 
Some participants had also faced lack of consent from their family when they were younger as there had only been one car in the immigrant household. This was now having negative consequences as their inability to drive made it harder to look for employment and to seek better career opportunities:

"And (my dad) actually put his foot down and he didn't let us get a driver's license. And I remember, my sister and I, we were just so upset about it...[discusses Montreal travel experiences] But when we moved to Toronto, the issue of public transit... when it wasn't as comfortable to take public transit because of the issues I mentioned, so then we realized that we should have at least gotten our driving license long time ago." (Selina)

Some of the participants further explained that the reasons they never learned to drive was because other cities they had lived in before, such as Montreal, London and New York, had excellent transportation networks. Selina stated: "One of the reasons I don't have a driving license is that Montreal spoilt me. I didn't feel a need to have a driving license in Montreal. Everything is so accessible". Likewise, Maya shared that "because I lived in New York city most of my life and there we have an excellent public transportation system, it would be a financial burden if you actually had a car, unless you lived on the outskirts".

In contrast, looking for work without a driver's licence in Toronto presented major challenges. In Selina's terms, learning to drive was a "dire necessity". Similarly, Maya expressed, "I think to be mobile in Toronto, you need to have a license or access to a car". In the face of reduced work opportunities and strenuous grocery shopping routes on public transit, cars emerged as the privileged solution to mobility barriers facing young immigrants in particular.

\section{$\underline{\text { Costs }}$}

The high cost of transit had a unique bearing on my interviewees. The participants commented that the price of individuals fares as well as monthly metropasses was simply too high. As Moses put it: "Yeah, man, three dollars is expensive for me, for me... Three dollar expensive, they must know, that expensive, they must know". Participants noted 
that as recent immigrants who were still settling and seeking better jobs and economic opportunities, they were on a tight budget. As Maya put it, "You know, and I think that if you are charging three dollars here, that's ridiculous. Especially for newcomers and people without jobs and there is like, no options for people like us." This concern was shared by recent immigrants such as Selina: "We are not new immigrants anymore, but we still operate within a certain budget”.

For many, the high fare meant that they had to resort to walking in order to get to work or do their grocery shopping, as they simply could not afford to pay for public transit fares. As Moses stated: "Realistically, I'm not really a walker, but I just walk to work because of circumstances, realistically". Increases in transit fares forced some participants to change their travel mode choice and payment options. Initially, John and his wife had used two metropasses. They then started sharing one metropass. Eventually, they switched to walking and now used tokens when needed: "Because they started to increase the prices every year you know, it was an unnecessary expense. So basically it is only if I have to go somewhere far, but now I walk more”.

However, resorting to walking comes with its own challenges. Geeta shared how when she was younger she was able to walk to get around the high fares. As a result of being older now and having health problems, walking was no longer possible. She further expressed concern over the price increases for alternative transit services such as the Canes Seniors Ride Connect: "Now they have increased the rates. They used to charge 5 dollars for this area. Now it has become, depending on the kilometer, a little bit more". Since services for people with disabilities were limited, she further shared that she at times had to use expensive taxis: "But now, if I take cab...sometimes I have taken a cab to Humberwood, I would be paying 15, 17 dollar. I had already paid a 130 dollars for the pass too. So, it was expenses".

Like John, several participants resorted to strategically sharing metropasses amongst family members, only buying metropasses during particular months depending on their schedule and the weather, or deciding to stay at home. Selina shared: "Sometimes I wouldn't buy metropass and I am like... I am just going to use tokens because I am not going to school for a full week. So it is not worth it for me to buy a total 
pass. So sometimes, you know, you might make these kind of strategic decisions on your transportation spending". Another participant, Ameena, avoided buying metropasses in the winter as she stays at home more then: "The winter months I usually don't, cause it is cold and people don't usually go anywhere... it's just cheaper to use tokens".

Again, participants compared their experiences in Toronto to other cities that they have lived in, noting the higher costs of using transit here. One participant pointed out that Montreal, the city she first settled in, has public transit that is both better and more affordable. Toronto's high cost of transit meant that she even occasionally had to skip her classes:

"When I went to Toronto to do University, I was absolutely shocked at the transportation. I didn't plan for this, I had a lot of trouble, because I just didn't plan for the money, you know, I was in a tight budget. I remember even missing some classes. I was like I don't have money to go to class today”. (Selina)

This again highlights the close interrelationship between access to transit and social and educational opportunities more generally.

\section{Transit and Grocery Shopping}

In addition to getting to work, shopping for groceries emerged as a unique struggle - especially for immigrant women. Mobility barriers to grocery shopping are a direct outcome of a built environment that does not provide adequate walkability to stores. Older participants in particular argued that the long distances made it difficult for them to carry their groceries home. Geeta shared how she chose small local stores over cheaper supermarkets: "I buy from very local shops, which are very close to TTC, small little shops... like Chinese stores... little little shops. Because they have vegetables. Because I can't walk in a big store". Other participants, like Selina, would choose to go in pairs - especially on weekends when the day pass allows two adults to share as well as accompanied children: "When we do grocery shopping, it is just easier if two people go, because then we can carry more and we can buy groceries for the month". 
Furthermore, participants noted that buses, streetcars and subway stations were not accessible and were inconvenient to travel on with large amounts of groceries. Some respondents would opt for walking, either because of the high fare, or because they had difficulty getting their groceries carts onto streetcars and buses. Eve noted that bus drivers do not lower the ramp for grocery carts - so instead, she would drag her cart home: "I found that when you have a grocery cart, it is hard to get on the bus, or off, it is heavy, you have to lift it up, and they don't move the bus down for you to pull the cart up, unless you have the stroller or wheelchair". Likewise, Moses shared her struggle with the buggy: "I want to take the streetcar, but just because of the buggy, the buggy be so much time to put into the streetcar because of its height, and so many time taking it out, so it's best to walk".

Such difficulties were compounded for immigrants who did not have access to ethnic food in the areas where they lived. One participant who chose to live in the YongeEglinton area to be close to the subway had to go all the way to St. James Town and Regent Park in order to buy Halal meat and other food linked to her diasporic origin. Traveling for grocery shopping was challenging especially in the winter. Selina said she changed her diet as a result of these traveling limitations: “[S]ome months, we just don't eat meat at all, because I just don't want to make the trip there to get groceries. That issue happens in the winter a lot".

This section brings to the fore that immigrants who do not own or have access to a vehicle are forced to depend on public transit or walking for daily activities such as shopping - both of which are challenging. The next section discusses accessibility of transit and the built environment in greater depth as it closely relates to the gendered experiences of the participants.

\section{Accessibility and the Built Environment}

Accessibility of the infrastructure and of transit vehicles had a significant bearing especially on immigrant women. Activities such as grocery shopping and traveling with children are highly gendered. As mentioned earlier, participants noted the difficulty of 
getting onboard streetcars and buses with grocery carts. Subway stations were also often full of barriers. Elevators could be absent or fail to accommodate people with disabilities or strollers. Eve shared her negative experiences of traveling on the subway while being pregnant: "I was probably seven, eight months pregnant, and nobody gave me a seat". She also described her difficulty in traveling on transit with her children: "We lived at Lansdowne and Bloor, and that station didn't have the elevator. So I had to, well usually, I had to travel with my husband, I cannot really go by myself cause I cannot carry the stroller and her down the stairs, so that was very inconvenient". Even participants who did not have children expressed concern for mothers traveling with children and strollers. As Maya stated: "I really empathized with the mothers with the strollers, the one at Pape station, if you are going downtown, there is no down escalator to get there, so it's this huge set of steps, of stairs that you have to take, so it's not really very communityfriendly".

As discussed earlier, accessibility also had particular significance for older immigrants. The Wheel Trans service by the TTC only caters to permanent disabilities. Old age and general health problems are not generally accommodated by Wheel Trans. For Geeta, this caused extreme challenges:

"I have auto-immune conditions too. And I've been to TTC for that TTC Wheel Transit. So that they can come pick me up. But they refuse. They say they need more information. And my balance has become so low and I told them I wasn't able to work. So now, I don't go anywhere because I don't have energy and it is very difficult for me to get into the bus, get out of the bus. Because some buses don't have the lower it down... Some drivers do it. Some drivers don't. There is too much effect on my joints." (Geeta)

Another participant, John, who worked as a personal support worker confirmed that transit definitely needs to become more accessible and better service people with disabilities. According to him, public transit has improved to a certain extent in that many buses now accommodate people using wheelchairs. More needs to be done, however, to make subway stations and streetcars accessible, too.

In addition to poorly accessible transit infrastructure, the built environment had further impacts on participants, again affecting women doing grocery shopping and older immigrants in particular ways. Some participants noted that it was hard to walk on 
unploughed sidewalks. Some large stores, further, have huge setbacks from the bus stops that are challenging to navigate. The lack of walkability of the built form and the poor servicing of sidewalks for pedestrians was a major concern for Moses:

"Every time the streetcar pass me I think, whao, I wish I was on that. For real. All the time. All the time. And then I look up on the road and see a sidewalk full of pure ice and I have to take time walking and I say I wish I would be on the streetcar". (Moses)

Other participants, like Geeta, shared how difficult it was to walk the lengthy distances between bus stops and destinations: "For the bus, it leaves you somewhere and then you have to walk a lot. When we come to gurdwara [Sikh temple], there are days I cannot walk from bus stop to gurdwara". As such, the accessibility of transit infrastructure and vehicles is not the sole barrier but also the poor design, layout and urban form of the built environment that closely determines mobility for elder women. Some respondents, especially older ones, shared how the autocentric built environment and unploughed sidewalks caused safety problems for them, as they had slipped and fallen, causing considerable anxiety. As Geeta shared: "It was becoming increasingly difficult for my joints, for my mental health, for my physical health. And then I couldn't do it anymore. Then, I slipped also when I was crossing for the bus". Elena shared a similar experience of her troubles getting to a bus stop: "To reach the bus stop, I had to cross the lane, which is icy, so it made no sense because by the time I catch the bus, I am exhausted [...] I had couple of falls walking on the snow. So it's pretty much unsafe".

In addition to difficulty in using public transit for grocery shopping, accessing work opportunities and navigating the built environment, participants were also affected by numerous transit service problems, as the next section briefly outlines.

\section{$\underline{\text { Transit Service Problems }}$}

\section{Commuting Time}

Several interviewees described their struggles in navigating long commutes. Some had moved to more downtown locations in order to reduce their commuting time. John shared his challenges attempting to catch the first train in the morning in order to 
commute downtown from Scarborough every morning: "I'd have to take like one bus to the subway station, then take the train downtown, then take another bus to work, so that used to take up a lot of my time". Like John, Mani chose to move further downtown in order to reduce his commuting time. Selina discussed her sister's long commute. Unable to afford GO Transit, she would choose to commute using TTC followed by an interchange at Islington Station from where she would get onto Mississauga Transit. "She has to spend 10 dollars. She is not happy with it because it costs her. Not just in terms of transportation, but also it costs her in terms of time... in terms of time that is wasted from her day".

\section{Unreliable, Infrequent and Poor Service}

Many interviewees were discontented with unreliable and infrequent service or poor connectivity that again served to prolong their commute times. A careful examination of the transit issues discussed in this sample also shows that commute times were often not the source of the problem but that there were deeper issues tied to them. In two instances, participants shared their transit experiences in other cities, New York and Montreal. Even though the commute there is long as well, the rapid transit network is more extensive and covers more ground and distance. Maya stated: "I'm used to long commutes, even though it's more like, the commute in New York would essentially take me further in distance than it does here... I feel like it's not well laid out here...”.

Poor servicing of buses particularly stood out in the responses. Interviewees expressed that buses would not show up on time, were overcrowded, or would arrive late in groups and sets. Some participants compared their experiences on the bus and on the subway and noted the stark difference: "Usually, the subway is not too bad, but the bus is a problem" (Eve). Lack of night time service was also important as many participants depended on transit outside of work: "In the night, they think nobody is there. So we suffer a lot for those buses" (Geeta).

To a lesser extent, subway delays and streetcar short turns presented an inconvenience to participants living in more downtown locations. Such interviewees shared that they would like to be better able to plan their trip or choose a different route 
or transportation mode for their work. "They keep on short turn, short turn, short turn and you know, you could make choices if you want, if you know the car is not going that way up front" (John).

\section{Bus Shelters}

Another major area of concern highlighted by many participants was the insufficient provision of bus shelters. This was especially a concern for individuals who extensively used bus networks for daily mobility and for getting to work. Challenges in the winter and cold weather stood out as lack of or sometimes overcrowded bus shelters didn't provide adequate protection and comfort: “...just standing in the cold, I'd be freezing by the time I get to the school or get home". Some participants such as Mani and Ameena noted that busy large intersections had bus shelters but that they were generally missing in residential communities close to where they live: "The one close to my home, there is no bus shelter".

\section{Other Issues: Discriminations, Isolation and Environmental Problems}

\section{Discrimination}

Some of the participants drew attention to more or less subtle forms of exclusion that they experienced or observed on public transit. Some interviewees shared that drivers would often give preferential treatment to people of certain races. Geeta, for example, shared an instance in which her daughter's pass was confiscated by the driver: "My daughter had very bad experience. The TTC driver was so racist. He confiscated her pass. And my daughter had to pay. I don't know why he did that'. Mani, likewise, shared a racist encounter that he observed as well as shared his own experiences of being harassed on the bus.

Other participants described competitions over public space on transit, which often took the shape of resentment against fellow travelers. This was gendered as women with small children and strollers were frequent targets. As Selina shared, for a woman with a stroller using transit is difficult as "other passengers end up resenting her. And she 
ends up resenting the passengers because she feels discriminated against because she has a child and she has a stroller. It's a competition almost for space with the bus".

\section{Isolation}

Many participants expressed feelings of isolation that resulted from the poor connectivity, poor service and high cost of public transit. As a result, participants like Moses often chose to stay home rather than going out to meet friends: "Because of the bus fare, three dollar expensive, and I don't have enough money. So, sometimes I'm in the house, I must keep myself quiet". Selina, too, wasn't very happy with her quality of life in Toronto. Often, she was unable to meet her friends who live in Mississauga. As stated earlier, she had also skipped university classes as a result of the poor connectivity within the GTA. For Eve, traveling with her daughter on public transit was impossible as stations are inaccessible and vehicles do not accommodate strollers: "We didn't really go anywhere because of that. I didn't really take her anywhere out of walking distance".

\section{Environmental Problems}

Some of the immigrants expressed concern for the environment, especially with the pollution that cars and automobiles were causing. One person, Geeta expressed that it isn't right for each person to drive one car: "When traffic is too much, so many cars, one, one person. It's criminal ways, wasting energy, energy which is limited". Similarly, Selina shared that she and her sister don't want to switch to a car as they believe in less cars on the street and preferred environmentally friendly transportation. However, she went on to state that "the system is forcing me to become a consumer of cars. It is not helping me with transit friendliness".

\section{Improvements}

Participants saw plenty of scope for improvement. The areas of improvement that they highlighted were often closely related to their transit experiences and their housing locations. 


\section{Harmonizing Fares}

As cost had such a big impact on transit users, many participants identified a need to rethink the current fare system. One recommendation made by several participants who needed or wanted to go around the GTA was to harmonize fares across the GTA. These interviewees currently had to pay doubles fares as they had to switch from the TTC to Mississauga Transit or York Region Transit. This was too costly and often prevented them from job opportunities and from participating in social activities. Selina expresses her perspective: "I think Toronto area regional fare service needs to be harmonized. Right now, it's really costly. During the year, I have really close friends who really improve my quality of life and they live in Mississauga and I don't get to see them often". Another participant who lived close to the boundary of Mississauga and Brampton explicitly called for a more universal network and fare across the GTA:

"Another thing I want is there should be a universal.. thing. Like, for example, if you have to go toward to Mississauga and Brampton, we have to pay different, different fares. And it is too expensive for us to pay. For one trip around, it costs around 10, 12 dollars, plus. So it doesn't make sense that way." (Geeta)

\section{Bus Networks and Shelters}

The need for improvements to the bus networks, service and shelters particularly stood out for immigrant participants living in the inner suburbs. Participants shared that some areas should receive more attention as they needed a more equitable transportation network: "Like the buses in this area, there should be more equity... equality... these things. They should really pay more attention to these areas" (Geeta). For Ameena, increasing bus service and having better routes were important: "I do definitely think they could rethink some of the routes in the city, and maybe increasing bus service, especially like where I take the bus sometimes, it is really like, half an hour, sometimes even every hour". Improvements to bus shelters and waiting areas were also significant as many participants found waiting times difficult to bear, given infrequent bus services and inadequate protection from the weather. As Maya stated: "when you go up to the platform to take the buses, it's not covered. That's another thing, they should make it so that people are not like freezing in the winter, standing in the snow waiting for buses". 


\section{Better Connectivity and Extensive Network}

Some participants called for a more extensive subway and rapid transit network. Maya, for example, was unimpressed by the existing number of subway lines and compared Toronto to other cities, for example in India, which had better and more extensive networks: "I mean what is this, two lines, two and a half lines?... Um, for a city of this size and diversity, I think the subways are very limited in terms of how much they, how far they go. Yeah, there are subways in India that are better". One participant, Elena stressed the need for a better connection to the airport, noting that she often had to take a cab to the airport at late night or early morning. She brought examples from Chicago and Bern and expressed Canada can do better and can go beyond the business of ParknFly: "If there can be connection between Kipling and the airport, it would be fantastic for passengers and it's a bonus" (Elena).

\section{Other Improvements}

Other, smaller, improvements were also recommended - notably providing live vehicle information through digital screens at bus stations and stops. Furthermore, interviewees argued for the need to provide better customer service by announcing delays or short turns early on, and being polite and responsive to riders. Some participants shared that transit operators could undergo better training particularly around cultural understanding and sensitivity. Moreover, one participant suggested having certain buses in lieu of, or complementary to, streetcars as a way to get around the slowness and unreliability of streetcars: “On Gerrard and Dundas, maybe...I can't speak for Queen and King, but maybe it would be good to have buses running along with the streetcars" (Moses).

\section{Kev Lessons from the Interviews}

The interviews conducted for this research opened up key perspectives on the travel patterns of immigrants in Toronto and their barriers to better mobility around the city. Participants were predominantly transit-dependent and used public transit for all activities. As such, my findings complement and interpret the statistical literature (Heisz 
and Schellenberg, 2004) on trends of higher public transit usage amongst immigrants in Toronto and the gendered nature of modal choice.

A number of mobility barriers and problems were highlighted in this study. Some participants were strongly impacted by long commute times, with which the spatial mismatch literature is generally concerned. However, participants were often more concerned with the number of interchanges, the inaccessibility of stations and stops, the absence of bus shelters, and unreliable and infrequent service. In other words, the significant barrier is not commute time in itself; but rather, the poor service and connectivity that cause long commutes in the first place. My participants confirmed emerging research in the areas of transportation behaviour and policy studies (Blumenberg, 2004) that attempts to shift attention to bigger transit issues such as connectivity and accessibility rather than travel time per se. Given the small sample, this research cannot provide a conclusive commentary on the spatial mismatch hypothesis. Nevertheless, the fact that some participants were impacted by long commute times, which at times limited job opportunities, underlines the urgency of further research on this topic.

Furthermore, participants emphasized service problems when asked about what improvements they wanted to see in public transit. Reliability and frequent service, a better-connected network, as well as bus shelters, stood out as key areas that participants wanted to see improvements in. These findings suggest that immigrants can benefit significantly from an improved bus network. As most of the immigrants in the study were transit-dependent, they were strongly affected by infrequent night and weekend service. My data thus support some of the existing literature on transit-dependent communities, such as the participatory action research in Vancouver, that drew attention to the underinvestment in bus networks and services (BRU, 2005). Issues of spatial and social inequities were also underlined by participants, many of whom had limited housing options and lived on a tight budget. Interviewees' perspectives on their housing choices and decisions confirm much of the emerging housing literature that raises concern about the decreasing availability of affordable rental housing stock in downtown Toronto and the difficulty in finding affordable rental housing near rapid transit (Murdie and Teixeria, 
2003; Walks and Maaranen, 2008; Thomas, 2011; Hulchanski, 2010). The complexities of immigrants' spatial and social locations and the multi-layered barriers to their mobility confirm some of the structural concerns raised in the broader transportation and environmental justice literature.

The racialization and gendering of space on transit, illustrated by the experiences of women with strollers and accounts of discrimination and struggle over public space, further corroborate findings generated by previous researchers. For example, Jasmin Zine (2008) has noted that Muslim youth often face racialized and gendered name-calling by passengers on the TTC, and that transit drivers sometimes skip them without stopping.

Many interviewees highlighted the cost of transit as a major concern. Some called for a universal affordable fare across the GTA. This reaffirms the challenges that Khosla (2003) identified for low-income women in Toronto. Additionally, some of the immigrants whom I interviewed resorted to walking, either because they were unable to afford public transit fares or because transit was inaccessible for strollers and grocery carts. These patterns support Hess's and Farrow's (2011) data that many women walk, even when the built environment is not conducive to walkability in order to carry out gendered tasks such as grocery shopping.

Moreover, when participants shared that they wanted to switch to a car, or were working to get a driver's license, it was generally a decision based on necessity rather than that of lifestyle choice. In other words, the inaccessibility of traveling with children and grocery shopping in an autocentric built environment, and the inability to reach economic opportunities on public transit, are forcing transit-dependent riders towards the automobile. These findings complement some of the transportation studies carried out in the United States, that underline the benefits of an automobile for low-income communities and for immigrants (Blumenberg and Manville 2004, Blumenberg 2009). The findings generated with my interview participants may shed some light and direction for further research into why some immigrants in Toronto would switch towards car usage after having already settled in. 
More importantly, what this research brings to surface is that unless transit agencies start paying attention to their transit-dependent riders, public transit will lose immigrant riders who may eventually either resort to walking or switch to driving altogether. In the concluding chapter, I discuss some of these challenges and gaps in existing transportation strategies and provide some recommendations for transportation policy. 


\section{CHAPTER 6 - MOVING FORWARD: IMMIGRANTS AND TRANSPORTATION POLICY}

My study of immigrants and transportation in Toronto comes at an important moment. Decisions to build a downtown priority subway line and approve new revenue generation tools are currently under way. Meanwhile, new LRT lines that were long approved have been phased out for construction. However, many of these discussions and decisions tend to sideline immigrants, even though they are often transit-dependent and, as such, significantly impacted by transit policies and strategies. This research project thus provides insights into an important community in Toronto as immigrants have much to gain from transit improvements. My findings have highlighted the limited affordability of public transit, the poor servicing and connectivity of bus networks, and the resulting barriers to accessing work opportunities across the region for many immigrants. In this conclusion, I review and evaluate some of the transportation strategies and policies introduced at the beginning of my paper by placing them alongside the interview accounts. I identify some of the gaps in the existing transit strategy and make recommendations on how to change existing strategies and policies in a way that bring us closer to goals of both sustainability and environmental justice.

\section{Gaps and Challenges in Transit Strategy}

The current push by the city and province for an expanded rapid transit in Toronto can be an invitation and an opportunity to bridge some of the spatial and social divisions. Moreover, some councilors and leaders, such as past mayor David Miller, have championed a move for transit to serve "priority neighbourhoods". Nevertheless, it is noticeable that there is no clear-cut vision or strategy on how transportation provision can act as social and spatial equalizer. At the regional scale, the transportation strategies have focused on economic growth, commuter rapid transit and sustainable transportation in the face of climate change. At the municipal scale, on the other hand, there have been competing preferences and limited adherence to an effective transit vision and plan on the part of politicians. The data generated in this study confirm that a multi-scalar perspective 
is necessary. Indeed, many of the transit users interviewed here constantly cross the border between the local and the regional, highlighting the need to rethink connectivity between Toronto and GTA in ways that cannot be achieved at the local scale alone. As I highlight, the current focus on 'choice riders', climate change and urban grown centres does not adequately address the concerns of the transit-dependent communities from which many of the immigrants interviewed in this study hailed.

\section{'Choice Riders’ and Transit-dependent Riders}

A major strategic challenge in moving forward with transit expansion and investment in infrastructure is the tendency of transit agencies to prioritize transit 'choice riders' rather than transit 'captive riders'. It is of course crucial for a strategy to market and build transit with a goal to generating resources for funding infrastructure, covering service costs and encouraging people to get out of the car and onto transit. Nevertheless, overlooking transit 'captive riders' has negative impacts on transit-dependent communities. Prioritizing 'choice riders' over transit dependent riders also generates a public transportation network that disproportionately favours middle-class white populations and commuter rail networks. Racialized populations that depend more on bus networks, on the other hand, get overlooked.

Moreover, the immigrant perspectives that emerge from this research challenge the dichotomous assumptions generally held in the transportation industry of transit 'choice riders' and transit 'captive riders'. With the exception of one, all participants in this study are transit dependent. However, the accounts by these transit-dependent riders reflect an expectation of a high degree of reliability and good customer service that matches the commonly associated expectations of 'choice riders'. My findings further suggest that when transit contains barriers and mobility becomes restricted, riders resort to walking. One participant switched over to a car. Many others started making efforts at getting a driver's license or possibly acquiring a car in the future. As such, communities that today may be transit-dependent may tomorrow be automobile users because the public transportation system neglected to provide for them. 


\section{Climate Change, Global Cities and Environmental Justice}

A major catalyst behind existing rapid transit expansion in the city is the current wave of environmental interest in reducing greenhouse gas emissions and other pollutants that are caused by automobile use. Moreover, stakeholders in Toronto desire to turn Toronto into a more competitive global city (Keil and Young, 2008). These strategic considerations again tend to lend greater support for investment in rail-based transit than in bus transit (Keil and Young, 2008). While it is important to have a transportation expansion strategy that is sustainable, any notion of sustainability should also encompass ideals of social equity and justice. As many of the interview accounts illustrated, servicing bus networks is a crucial part of this. An environmental justice framework that takes into consideration the transportation barriers of racialized and low-income communities is relevant in this context. By expanding an environmentalist critique of an unsustainable car culture to an environmental justice critique of inaccessible transit, we can build bridges in order to ensure that capital investment in new transportation infrastructure will also benefit immigrant populations, who heavily rely on local transit buses.

\section{Smart Growth but where?}

The interview accounts generated in this study have important implications for the regional and municipal policy that I outlined in the introductory chapters. In particular, they shed a new light on current transportation-related growth strategies. Policies for smart growth are predominately directed towards identified urban growth centres, downtown areas and avenues. Many of the inner suburban residential and apartment neighbourhoods, as a result, may not benefit from smart growth policies, at least in their transportation-related aspects. More attention is needed to expand the paradigm of smart growth and improve transit in some of these residential inner suburbs. 


\section{Policy Recommendations}

The data generated in this study point to a number of policy recommendations and transportation planning interventions. There is a need to shift transportation strategy towards an environmental justice framework that is grounded in the needs of racialized and low-income transit-dependent riders, many of whom are immigrants settling in inner suburbs. In conceptualizing the environment as a place where people "live, work and play" (Bullard 2009: 20), transportation policies must be examined in a holistic manner that looks at transit alongside opportunities and access to housing and employment for immigrants. My recommendations and interventions are as follows:

\section{Harmonize fares across the GTA at an affordable rate.}

This would ensure low-income immigrants who depend on public transit are able to get across the region for job opportunities without a cost hindrance. As well, it would build social capacity amongst low-income communities in that it would enable people to visit friends and family, participate in social networks and go shopping in other areas.

2. A greater investment in bus networks.

This would include better and more frequent service, including weekend and night service. There also needs to be greater provision of bus shelters and better customer service through live vehicle information. Transit City Bus Plan has identified a few bus rapid transit corridors. Additional bus rapid transit corridors may have benefit to transit-dependent communities. Further research is needed to study riders' experiences with and barriers to bus rapid transit.

3. The downtown priority line should serve as a regional priority line.

This line should connect to neighbourhoods in East York (Flemingdon Park and Thorncliffe Park) and on the west side to Etobicoke. Such a line would better link the areas where many of immigrants reside and thus provide increased connectivity and mobility over rapid transit for these communities. This kind of regional line is also advocated by transportation engineer and planner Edward Levy (2013) as a way of connecting "priority neighbourhoods" to public transit. 


\section{Integrating land-use policies.}

New rapid transit lines developments should be integrated with effective land-use policies that encourage a mix of commercial, retail and residential use. A mix of housing should be encouraged. There should be further research into how policies such as inclusionary zoning might sustain and promote affordable and rental housing stock along rapid transit corridors.

5. Changes in the design and form of the built environment.

In the long run, neighbourhood design should facilitate more walkable and pedestrian friendly features. Possible starting points include effective land-use planning, site planning and design guidelines. Smart growth policies have put some of this in place in identified growth centres, but more needs to be done with regard to the numerous residential and apartment neighbourhoods in inner suburbs such as Rexdale, Thorncliffe Park and Malvern where many immigrants now live. Such a policy will also enhance accessibility for immigrant women, who are currently struggling with gendered barriers to their mobility when carrying out daily tasks such as grocery shopping or travelling with children.

6. Progressive revenue generation tools.

New taxes should be evaluated with an environmental justice and social justice framework in mind (Cairns, Greig \& Waches, 2003). Tools such as payroll tax, congestion charge and high occupancy tolls may be preferable over regressive taxes (for example, property tax, increased transit fares, sales tax). This is an important consideration since many immigrants, like participants in this study, cannot afford the existing cost of transit fares. Further research is warranted to assess these revenue generation tools and their impact on low-income immigrant groups.

\section{$\underline{\text { Outlook }}$}

This study has provided a first insight into Toronto-based immigrants' experiences of getting around in the city and making transportation-related choices within the major constraints that they face. It goes some way towards helping us interpret and explain existing statistics, including that $36.3 \%$ of immigrants use public transit in Toronto CMA compared to $20.7 \%$ of Canadian-born person (Heisz and Schellenberg, 
2004: 172-173). On a more fundamental level, the interview accounts assembled here shed light onto the complex interrelationships between housing affordability, spatial location, work opportunities, gender divisions and the built environment, on the one hand, and immigrants' transportation barriers on the other.

Further research is needed in order to explore more comprehensive planning interventions that adequately address these interrelationships. In particular, case studies of particular neighbourhoods or of specific immigrant communities could be useful to shed light on differences between how transit barriers are experienced by various communities and in various spatial locations. Researchers might also ask why immigrants are switching to cars, and what kind of transportation policy is needed to respond to this. In addition, a qualitative study that explores immigrants' accounts of transportation across the GTA in relation to employment opportunities would be suitable for addressing some of the questions raised in my research in greater detail, and in a way that goes beyond its focus on Toronto.

In this study, I have laid some of the groundwork in calling for a shift towards a new transportation strategy: one that better attends to transit-dependent riders, emphasizes environmental justice and social justice and caters to the inner suburbs, where many immigrants are presently settling. This would be grounded in a holistic approach to transit alongside housing and employment. In planning practices, a seamless integration of transportation planning and land-use planning with better attention to environmental justice can ensure adequate rental and affordable housing stock along LRT and subway lines in Toronto. A mix of affordable rental housing and increased density along rapid transit corridors can address some of the social and spatial divisions discussed in this paper.

Finally, I end with an insightful quote from one of the immigrant participants that captures an important lesson for politicians, transportation planners and policy-makers: "It (transit) is a lifeline of the city. It is your backbone. It takes you around. You cannot survive without TTC bus services and streetcars and subways. You do need it. Because it's faster and better. Faster than cars too, right?" (Geeta) 


\section{APPENDIX A - INTERVIEW GUIDE}

Research Project: The Place for Immigrants in Toronto's Transit and Transportation City

Principal Investigator: Amardeep Kaur

\section{$\underline{\text { Public Transit Use }}$}

1. Tell us how you use transportation in Toronto.

2. How often do you use public transportation? For what purposes?

3. How long does it take you to walk to bus stop or TTC station?

\section{Getting to Work:}

4. Describe your travel routine to work? (time of day, route, interchanges)

5. How much time does it take for you to travel to work?

6. Have you ever used Go Transit? Why or why not?

Other Activities:

7. How do you usually travel for other activities such as grocery shopping, personal trips, picking up children from school?

8. How much time does it take you for these errands?

\section{Driving and Car}

9. Do you drive? (If no, why not?)

10. Do you or your family own a car? How many cars?

11. If you own a car, when do you normally use it? Where do you go?

12. What transportation you like or prefer? Cars or public transportation? 
Issues and Factors

13. If you had the choice, where would you live in the city?

14. When you immigrated, how did you decide where to live? Was transportation a factor in your housing choice?

15. Do you own a metropass? If not, what is your normal mode of payment?

16. Do you know about the day pass option?

17. Are you aware of the stop request program?

\section{$\underline{\text { Improvements and Suggestions }}$}

18. Have you ever been to a community consultation meeting on transportation in the city? Why or why not?

19. Are there any other issues that make using public transportation difficult for you?

20. Do you have any concerns for the way public transportation is provided in Toronto?

21. What improvements do you want to see in public transportation?

\section{Demographics}

22. What is the nearest intersection/neighborhood you live in?

23. Do you rent or own your home? What kind? Apartment? Townhouse? Detached house?

24. How many people live in your household? Any children? Any elders?

25. What is your age-range?

26. How long have you been in Canada? What is your country of origin?

27. If you are working right now, what job sector are you at?

28. What is your annual income range? What is your household's annual income range? 


\section{REFERENCES}

Adler, M. (2012, August 24). Delay to Sheppard East LRT raises hopes of possible subway line. Scarborough Mirror .

Agrawal, S. K. (2008). Faith-based Ethnic Residential Communities and Neighbourliness in Canada. Planning, Practice \& Research , 23 (1), 41-56.

Agrawal, S. K. (2006). Housing Adaptations: A Study of Asian Indian Immigrant Homes in Toronto. Canadian Ethnic Studies , 38 (1), 117-130.

Basu, R. (2013). Integrative Multiplicity through Suburban Realities: Exploring Diversity through Public Spaces in Scarborough. Retrieved March 18, 2013, from CERIS: Ontario Metropolis Centre: http://www.ceris.metropolis.net/wpcontent/uploads/2013/02/Final_Report_Basu.pdf

Bauder, H. (2000). Reflections on the Spatial Mismatch Debate. Journal of Planning Education and Research , 19, 316-321.

Blumenberg, E. (2004). En-gendering effective planning: Spatial mismatch, low-income women, and transportation policy. Journal of the American Planning Association , 70 (3), 269-281.

Blumenberg, E., \& Manville, M. (2004). Beyond the Sptial Mismatch: Recipients and Transportation Policy. Journal of Planning Literature , 19 (2), 182-205.

Boudreau, J.-A., Keil, R., \& Young, D. (2009). Changing Toronto: Governing Urban Neoliberalism. Toronto, ON: University of Toronto Press.

Bullard, R. D., \& Johnson, G. S. (Eds.). (1997). Just Transportation: Dismantling Race and Class Barriers to Mobility. Gabriola Island, B.C.: New Society Publishers.

Bullard, R. D., Johnson, G. S., \& Torres, A. O. (Eds.). (2009). Highway Robbery: Transportation Racism and New Routes to Equity. Cambridge, MA: South End Press.

Bullard, R. (2009). The Anatomy of Transportation Racism. In R. D. Bullard, G. S. Johnson, \& A. Torres (Eds.), Highway Robbery: Transportation Racism and New Routes to Equity. Cambridge, MA: South End Press.

Bullard, R. (2005). Environmental Justice in the Twenty-First Century. In R. Bullard (Ed.), The Quest for Environmental Justice: Human Rights and the Politics of Pollution (pp. 1-42). San Fransico: Sierra Club Books.

Bus Riders' Union (BRU). (n.d.). Night Owl Buses: Towards Social Justice in the Vancouver Region. Retrieved March 15, 2012, from Bus Riders Union: http://bru.vcn.bc.ca/uploads/images/13/Night_Owl_Buses_Towards_Soc.pdf Bus Riders' Union (BRU). (2005). Women in Transit. Vancouver: Bus Riders' Union. 
Cairns, S., Greig, J., \& Waches, M. (2003). Enviornmental Justice and Transportation: A Citizens' Handbook. University of California Berkeley, Institute of Transportation Studies. University of California.

CBC News. (2011, December 9). MAP: Service cuts to TTC's busiest bus routes. Retrieved February 15, 2013, from CBC News:

http:/www.cbc.ca/news/canada/toronto/story/2011/12/09/ttc-map-bus-servicecuts248.html

Cervero, R., Sandoval, O., \& Landis, J. (2002). Transportation as a Stimulus ofWelfareto-Work Private versus Public Mobility. Journal of Planning Education and Research, 22 (1), 50-63.

Chen, D. (2004). Linking Transportation Equity and Enviornmental Justice with Smart Growth. In R. D. Bullard (Ed.), Growing Smarter: Achieving Livable Communities, Enviornmental Justice, and Regional Equity. Cambridge, MA: The MIT Press.

City of Toronto. (2007). Backgrounder: Release of the 2006 Census on Language, Immigration, Citizenship, Mobility/Migration. Retrieved March 12, 2013, from City of Toronto:

http://www.toronto.ca/demographics/pdf/2006_lang_imm_citizenship_mobility_backgro under.pdf

City of Toronto. (2010). Section 3.24 Transit City Light Rail Plan. In Council Briefing Book: 2010-2014. Retrieved February 19, 2013, from City of Toronto: http://transit.toronto.on.ca/streetcar/4121.shtml

City of Toronto. (2010). Toronto Official Plan, 2006. Retrieved from City of Toronto: http://www.toronto.ca/planning/official_plan/introduction.htm

Data Managment Group - University of Toronto. (n.d.). Transportation Tomorrow Survey. Retrieved November 20, 2012, from Data Management Group: http://www.dmg.uoftoronto.ca/transportationtommorrowsurvey/index.html

Debbane, A.-M., \& Keil, R. (2004). Multiple Disconnections: Enviornmental Justice and Urban Water in Canada and South Africa. Space and Polity , 8 (2), 209-225.

Ghosh, S. (2007). Transnational ties and intra-immigrant group settlement experiences: A case study of Indian Bengalis and Bangladeshis in Toronto. GeoJournal , 68, 223-242.

Go Transit. (2008). Strategic Plan GO2020. Retrieved November 11, 2012, from http://www.gotransit.com/public/doc/en/publications/Strategic_Plan_G0_2020_lowres.pd $\mathrm{f}$

Goddard, J., Rider, D., \& Kalanowski, T. (2010, March 26). Miller outraged as budget sideswipes GTA transit. Toronto Star .

Gosine, A., \& Teelucksingh, C. (2008). Environemental Justice and Racism in Canada. Toronto: Emond Montgomery Publications. 
Government of Ontario. (2005). Places to Grow Act, 2005 (S.O. 2005, c. 13). Retrieved 03 31, 2013, from http://www.e-

laws.gov.on.ca/html/statutes/english/elaws_statutes_05p13_e.htm

Heisz, A., \& Schellenberg, G. (2004). Public Transit Use amongst Immigrants. Canadian Journal in Urban Research, 17 (1), 170-191.

Hess, P. M., \& Farrow, J. (2011). Walkability in Toronto's High-Rise Neighbourhoods. Toronto: Cities Centre, University of Toronto.

Hu, L., \& Giuliano, G. (2011). Beyond the Inner City New Form of Spatial Mismatch. Journal of the Transportation Research Board (2242), 98-105.

Hulchanski, J. D. (2010). The Three Cities Within Toronto: Income Polarization Among Toronto's Neighbourhood, 1970-2005. University of Toronto. Toronto: Cities Centre Press, University of Toronto.

Kain, J. F. (1968). Housing Segregation, Negro Employment, and Metropolitan Decentralization. Quarterly Journal of Economics , 82 (2), 175-197.

Kalanowski, T., \& Rider, D. (2010, December 2). 'War on the car is over': Ford moves transit underground. Toronto Star.

Keil, R., \& Young, D. (2008). Transportation: the bottleneck of regional competitiveness in Toronto. Enviornment and Planning C: Government and Policy, 26, 728-751.

Khan, S. (2008). Transportation Justice. In A. Gosine, \& C. Teelucksingh, Environmental Justice and Racism in Canada (pp. 136-139). Toronto: Emond Montogmary Publications.

Khosla, P. (2005). Gendered Cities and Built Enviornments. Retrieved March 15, 2012, from The National Network on Environments and Women's Health:

http://www.nnewh.org/images/upload/attach/5912gendered cities EN.pdf

Khosla, P. (2003). If Low Income Women of Colour Counted in Toronto. Toronto: The Community Social Planning Council of Toronto.

Kitchen, H. M. (2003). Municpal Revenue and Expenditure Issues in Canada. Toronto: Canada Tax Foundation.

Law, R. (1999). Beyond 'women and transport': towards new geographies of gender and daily mobility. Progress in Human Geography, 23 (4), 567-588.

Lo, L., Shalaby, A., \& Alshalalfah, B. (2011). Relationship between Immigrant Settlement Patterns and Transit Use in the Greater Toronto Area. Journal of Urban Planning and Development , 137 (4), 470-476.

Lorinc, J. (2011, November). How Toronto Lost Its Groove. Retrieved June 13, 2012 , from Walrus Magazine: http://thewalrus.ca/how-toronto-lost-its-groove/ 
Maaranen, R. (Cartographer). (2006). Toronto Immigrant Settlement Trends by Neighbourhood (Census Tracts), 1961 to 2001. Retrieved November 12, 2012, from Centre for Urban and Community Studies, University of Toronto: http://www.urbancentre.utoronto.ca/gtuo/

Metrolinx. (2010, May 9). 5 in 10 Plan. Retrieved February 13, 2013, from Metrolinx: http://www.metrolinx.com/en/docs/pdf/board_agenda/20100519/Five_in_Ten_Board_we b.pdf

Metrolinx. (2008). The Big Move: Transforming Transportation in the Greater Toronto and Hamilton Area. Toronto: Greater Toronto Transportation Authority.

Miller, E. J. (1999). Panels and Other Survey Extensions to the Transportation Tomorrow Survey. University of Toronto, Department of Civil Engineering. Toronto: Data Managment Group.

Miller, E. J., Roorda, M. J., Haider, M., \& Mohammadian, A. (2004). Empirical Analysis of Travel and Housing Expenditures in the Greater Toronto, Canada, Area. Journal of the Transportation Research Board, 191-201.

Mitra, R. (2007). Evolution of Urban Form and Travel Behaviour in the Greater Toronto Area, 1986-2001. (Masters thesis). Kingston: Queens University.

Moore, A. (2012, June 7). Section 37: What 'Benefits' and for Whom? Retrieved October 15, 2012, from Munk School of Global Affairs, University of Toronto:

http://munkschool.utoronto.ca/imfg/uploads/199/aaron_moore_section_37_what_benef its_and_for_whom_rev_june_11.12.pdf

Murdie, R. E., \& Teixeira, C. (2003). Towards a Comfortable Neighbourhood and Appropiate Housing: Immigrant Experiences in Toronto. In P. Anisef, \& M. Lamphier (Eds.), The World in a City. Toronto: University of Toronto Press.

Murdie, R. (2002). The housing careers of Polish and Somali newcomers in Toronto's rental market. Housing Studies , 17 (3), 423-443.

Ontario. (2007, June 15). McGuinty Government Action Plan For Rapid Transit Will Move The Economy Forward. Retrieved February 13, 2013, from Government of Ontario: http://news.ontario.ca/opo/en/2007/06/mcguinty-government-action-plan-forrapid-transit-will-move-the-economy-forward.html

Ontario Ministry of Infrastructure. (2006). Growth Plan for the Greater Golden Horsehoe, 2006. Retrieved from Ontario Ministry of Infastructure:

https://www.placestogrow.ca/content/ggh/plan-cons-english-all-web.pdf

Ontario Ministry of Housing and Municipal Affairs (OMMAH). (2010). Height and Density Bonusing (s.37). Retrieved November 6, 2012, from Ontario Ministry of Municipal Affairs and Housing: http://www.mah.gov.on.ca/Page6845.aspx 
Ontario Ministry of Municipal Affairs and Housing (OMMAH). (2005). Provincial Policy Statement, 2005. Retrieved from Ontario Ministry of Municipal Affairs and Housing: http://www.mah.gov.on.ca/Page1485.aspx

Public Health, City of Toronto. (2012). Toward Healthier Apartment Neighbourhoods: A Healthy Toronto by Design Report. Toronto: Toronto Public Health.

Preston, J., \& Rajé, F. (2007). Accessibility, mobility and transport-related social exclusion. Journal of Transport Geography , 15, 151-160.

Reid, D. (2013, January 29). Zoning for Midrise. Retrieved February 13, 2013, from Spacing Toronto: http://spacing.ca/toronto/2013/01/29/zoning-for-midrises/

Rider, D., \& Kennedy, B. (2011, November 24). TTC slashes service on 62 routes. Toronto Star .

Rodrigue, J.-P. (2006). The Geography of Transportation Systems. New York: Routledge.

Stanley, A. (2009). Just space or spatial justice? Difference, discourse, and environmental justice. Local Environment , 14 (10), 999-1014.

Statitics Canada. (2012a). Toronto, Ontario (Code 3520005) and Ontario (Code 35) (table). Census Profile. 2011 Census. Statistics Canada Catalogue no. 98-316-XWE. Ottawa. Retrieved March 3, 2013, from Statistics Canada:

http://www12.statcan.gc.ca/census-recensement/2011/dp-pd/prof/index.cfm?Lang=E

Statistics Canada. (2012b). Canada at a Glance, 2012. Retrieved March 15, 2013, from Statistics Canada: http://www.statcan.gc.ca/pub/12-581-x/12-581-x2012000-eng.pdf

Statistics Canada. (2008, November 12). Census Snapshot-Immigration in Canada: A Portrait of the Foreign-born Population, 2006 Census. Retrieved 04 05, 2013, from Statistics Canada: http://www.statcan.gc.ca/pub/11-008-x/2008001/article/10556-eng.htm

Statitics Canada. (2007, March 17). Toronto, Ontario (Code3520005) (table). 2006 Community Profiles. 2006 Census. Statistics Canada Catalogue no. 92-591-XWE. Ottawa. Retrieved March 3, 2013, from Statistics Canada: http://www12.statcan.ca/census-recensement/2006/dp-pd/prof/92-591/index.cfm?Lang=E

Teelucksingh, C. (2007). Environmental Racialization: Linking Racialization to the Environment in Canada. Local Enviornments , 12 (6), 645-661.

Teelucksingh, C. (2002). Spatiality and Enviornmental Justice in Parkdale (Toronto). Ethnologies , 24 (1), 119-141.

Thomas, R. (2011). Resiliency in Housing and Transportation Choices: The Experiences of Filipino Immigrants in Toronto. (Unpublished doctoral dissertation) Vancouver, BC: University of British Columbia.

Toronto Transit Commission (TTC). (n.d.). Retrieved November 9, 2012, from http://www.ttc.ca/About_the_TTC/History/Milestones.jsp 
Toronto Transit Commission (TTC). (2009, August). Transit City Bus Plan. Retrieved November 22, 2012, from Toronto Transit Comission:

$\mathrm{http} / / /$ www.ttc.ca/About the_TTC/Commission_reports_and_information/Commission meetings/2009/August_26_2009/Reports/Transit_City_Bus_Pla.pdf

Toronto Transit Commission (TTC). (2007). The Transit City Light Rail Plan. Retrieved March 28, 2013, from Toronto Transit Comission:

http://www3.ttc.ca/About_the_TTC/Commission_reports_and_information/Commission_ meetings/2007/Mar_21_2007/Other/Toronto_Transit_City.pdf

United Way Toronto. (2011). Vertical Poverty: Declining Income, Housing Quality and Community Life in Toronto's Inner Suburban High-Rise Apartments. Retrieved December 1, 2012, from United Way Toronto: http://www.unitedwaytoronto.com/ verticalpoverty/downloads/Report-PovertybyPostalCode2- VerticalPoverty-Final.pdf.

Vincent, D. (2010, December 15). Light rail urged for low-income neighbourhoods. Toronto Star .

Walks, R. A., \& Maaranen, R. (2008). The Timing, Patterning \& Forms of Gentrification \& Neighbourhood Upgrading in Montreal, Toronto, \& Vancouver, 1961 to 2001". Research Paper 211 .

Walks, R., \& Bourne, L. (2006). Ghettos in Canadian Cities? Racial segregation, ethnic enclaves and poverty concentration in Canadian urban areas. The Canadian Geographer , 5 (3), 273-297.

Werkele, G. (2005) Gender Planning in Public Transit. In S. S. Fainstein, \& L. S. Servon (Eds.), Gender and Planning: A Reader (pp. 275-295). New Jersey: Rutgers University Press.

Zine, J. (2008). Canadian Islamic Schools: Unravelling the Politics of Faith, Gender, Knowledge, and Identity. Toronto: University of Toronto Press. 